Portland State University

PDXScholar

$5-1-1970$

\title{
Viet-Nam business education; a proposal for development
}

Hoang Ngoc Khiem

Portland State University

Follow this and additional works at: https://pdxscholar.library.pdx.edu/open_access_etds Let us know how access to this document benefits you.

\section{Recommended Citation}

Khiem, Hoang Ngoc, "Viet-Nam business education; a proposal for development" (1970). Dissertations and Theses. Paper 932.

https://doi.org/10.15760/etd.932

This Thesis is brought to you for free and open access. It has been accepted for inclusion in Dissertations and Theses by an authorized administrator of PDXScholar. Please contact us if we can make this document more accessible: pdxscholar@pdx.edu. 
AN ABSTRACT OF THE THESIS OF Hoang Ngoc khiem presented May $14,1970$.

Title: Viet-Nam Business Education: A Proposal for Development.

APPROVED BY MEMBERS OF THE THESIS COMMITTEE:

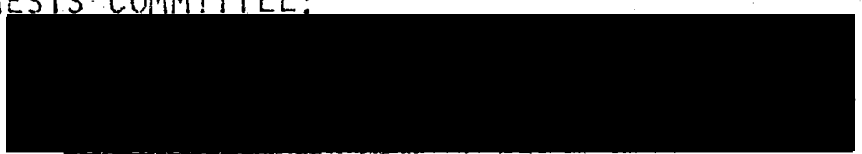

Leonard F. Robertson, Chairman

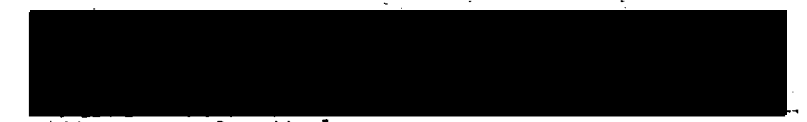

Morton S. Malter

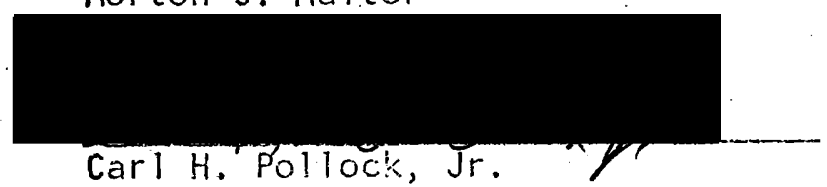

The Vietnamese educational system is humenistic, nationally

centered, and open to all cultural influence. The policy of Viet-Natn is to realize mass and practical education. However, the present systen is highiy selective and academicaily oriented. So far no business education program exists in the state university or in the public high school, but Viet-Nam is experimenting with comprehensive education.

This study was an attempt to present a proposal for the development of business education in Viet-Nam. It formulated the philosophy and objectives of business education in Viet-Nam in general both at the university and the secondary level. It also aimed to define the basic model of organization, curriculum development, and faculty recruitment and training.

The proposal was based on principles of business education widely accepted in American, Asian, and European countries and on the results 
of the analysis of the Vietnamese educational system and its environment.

It was revealed that, anywhere in the world, there is a vital need for a well-founded general education to be supplemented and complemented by various types of vocational education, one of which is business education. It was also conceived that, with reasonable adaptations, principles of business education developed and widely accepted in other countries may be applied in Viet-Nam.

As a result of the study, it was proposed that business education should be a related and integral part of the Vietnamese total program of education. In Viet-Nam today there is a great need for qualified business managers and competent white collar workers to strengthen the national business system. A strong business system is needed to facilitate the transfer of technology, to develop commerce and industry, to achieve economic independence, and to accelerate rehabilitation after the war.

The objectives of business education in Viet-Nam should be general for everyone, prevocational and vocational at the secondary level, and professional at the university level. Vietnamese business education should reconcile culture and career in order to provide competent employees, managers, and administrators who are socially, emotionally, intellectually, and civicly open-minded citizens.

The proposal also recommended that a Faculty of Business and a section of business education teacher-training of the Faculty of Pedagogy should be created in the state university. At the secondary level business education should be offered as general education in the traditional academic high schools and as vocational education in the 
upper. secondary schools of business and in the business education stream of the comprehensive high schools. Private business education institum tions should be encouraged as one segment of the national effort toward adult vocational education. A business educator training program should be planned and realized as soon as possible because it is vital to the development of a business education program. 
TO. THE OFFICE OF SRRADUATE. STUDIES:

The members of the Commitiee approve the thesis of Hoang Ngoc Khiem presented May 14, 1970.

Mr. Hoang's thesis is a study completed in addition to the degree of Master of Arts in Teaching (Business Education).

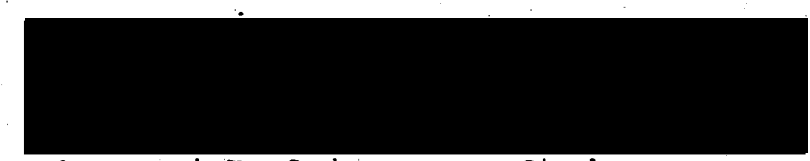

- Leonard F. Robertson, Chairman

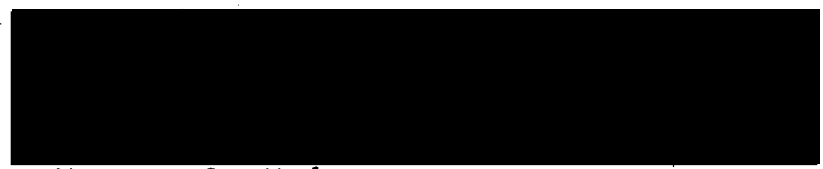

Morton S. Malter

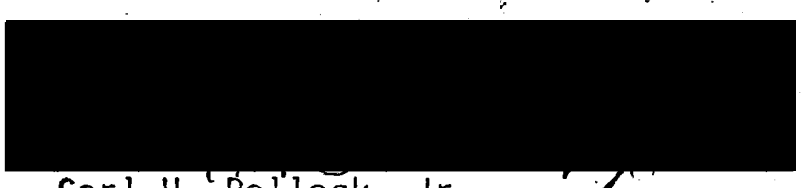

Carl H. Pollock, Jr.

APPROVED:
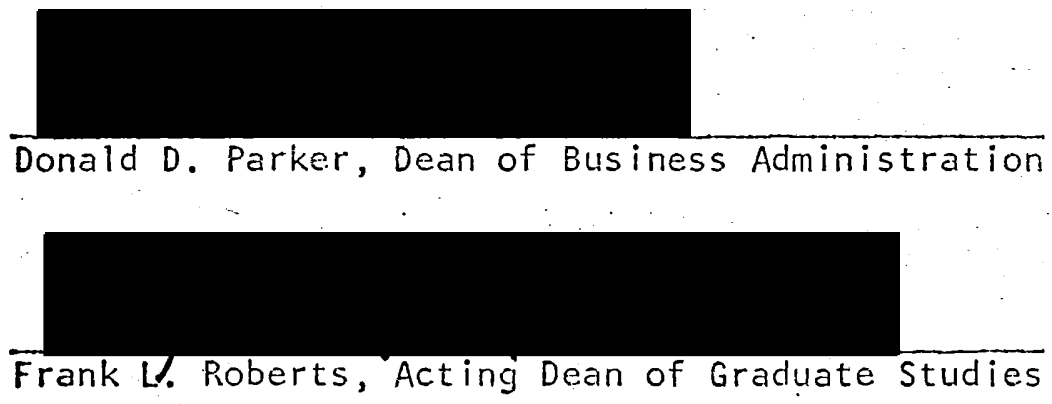
VIET-NAM BUSINESS EDUCATION:

A PROPOSAL FOR DEVELOPMENT

\author{
by \\ HOANG NGOC KHIEM \\ Master of Arts in Teaching \\ Business Education
}

\begin{abstract}
A POST-MASTER'S THESIS
submitted to the faculty of the

school of Business Administration
\end{abstract}

\author{
Portland State University \\ 1970
}




\section{ACKNOWLEDGMENTS}

I wish to acknowledge my indebtedness and express my sincere appreciation to $\mathrm{Dr}$. Leonard F. Robertson, my academic advisor, Chairman of the Business Education Department and Chairman of my Thes is Committee, who has given me guidance and the benefit of his experience in the development of the thesis.

I am also grateful for the advice and direction given me by my other two Thesis Committee members, Dr. Carl H. Pollock, Jr., and Dr. Morton S. Malter.

In addition, I appreciate the help in providing encouragement, materials, or advice for this study of Mrs. Gladys 0 . Philpott, my Program Development officer; Dr. Gilbert A. Stephenson and Miss Marguerite Appel of the Ohio University; and Mrs. Marie E. Brown, Administrative Assistant in the office of Graduate Studies.

I wish to thank Portland State University Library for the courtesy of its Interlibrary Loan Office and Mrs. Dianne Anicker, Mrs. Angela Spencer, and Miss Sandra Hobbs of the Business Education Department for their assistance in the completion of this thesis. 
TABLE OF CONTENTS

PAGE

ACKNOWLEDGEMENTS .................

LIST OF TABLES ...................... . . . . . . . . . . . . . .

CHAPTER

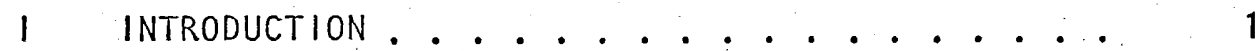

Introduction to the Problem . . . . . . 1

Statement of the Problem........ 2

Scope of the Problem .......... 3

Del imitations ........... 4

Definitions of Terms Used ....... 4

Methods and Procedures ........ 6

II BUSINESS EDUCATION IN COUNTRIES OTHER THAN

VIET-NAM ................. . . . 9

Philosophy and Foundations of Business

Education ........... 2

Business Education in the United States . . 12

Business Education in France...... 19

Business Education in Japan ...... 25

Business Education in India . . . . . 29

Business Education in Indonesia .... 32

Business Education in Thailand . . . . 36

Business Education and the Comprehensive

High School .......... 38 
CHAPTER

Characteristics of Business Education in

Countries other than Viet-Nam . . . . 42

III ANALYSIS OF THE VIETNAMESE EDUCATIONAL SYSTEM

AND ITS ENVIRONMENT . . . . . . . . . . . . . 45

The Educational System . . . . . . . 45

Organization ..................... 45

Basic Principles of National Education . 47

Technical and Vocational Education . . 47

Bus iness Education . . . . . . . . 49

Secondary Business Education

for Adults . . . . . . . . 50

The National School of

Commerce . . . . . . . 50

Private Business Institutions . $\quad 51$

Higher Business Education .. . . 53

The Faculty of Political and

Business Administration . . . 53

The National Institute of

Administration . . . . . . .

The Faculties of Law of

Universities ....... 60

Bus iness Skill Championship

Competition . . . . . . . . 61

Summary on Business Education .. . 62

Statistical Analysis........ 64

Environment . . . . . . . . . 71

Characteristics of the Vietnamese

Business system . . . . . . . . 71

Present Business Situation . . . . . . 77

Prospect of Postwar Business . . . . 79 
CHAPTER

Transfer of Technology and Educational

Investment.......... 82

Conclusion on the Analysis . . . . . . . 85

IV FINDINGS ON BUSINESS EDUCATION IN FOREIGN COUNTRIES

AND ON THE ANALYSIS OF THE VIETNAMESE EDUCATIONAL

SYSTEM AND ITS ENVIRONMENT .......... 90

Principles of Business Education . . . . . 90

Philosophy and objectives . . . . 90

Organization, Methods, and Curriculum : 91

The Vietnamese Educational System . . . . 93

organization and Principies . . . . 93

The Business Education System . . . . 94

Achievement of the Educational System . 95

Environment ........... . . 96

Summary of Findings . . . . . . . . 97

V A PROPOSAL FOR DEVELOPMENT . . . . . . . . . 99

Philosophy and objectives . . . . . . 99

Higher Business Education ..... 106

Philosophy and objectives . . . . 106

Organization of Higher Business
Education . . . . . . . . 107

Curriculum Problems . . . . . . 109

Faculty Problems . . . . . . . 114

Secondary Business Education . . . . . 115

Philosophy and objectives . . . . 115

Organization of Business Education at
the Secondary Level . . . . . . 118 
CHAPTER

$$
\text { Curriculum Problems ........ } 124
$$$$
\text { Faculty Problems.......... } 126
$$

Summary on the Proposal . . . . . 128

BIBLIOGRAPHY ................... 131 
I General Outline of Business Education System

in the United States ........... 20

II General Outline of Business Education System

in France .............. . . 22

III General Outline of Business Education System

in Japan .................. . .

IV General Outline of Business Education System

in India.................. 30

V General Outline of Business Education System

in Indonesia . . . . . . . . . . 34

VI General Outline of Business Education System

in Thailand............. . . . 37

VII General Outline of Vietnamese Educational

system ................... 48

VIII Three-Year Curriculum of the National School

of Commerce............. . . . 52

IX General Outline of the Four-Year Program at the

Faculty of Political and Business

Administration ............. 54

$X$ Curriculum of the Business Section of the Faculty

of Political and Business Administration . . . 
TABLE

XI General Outline of the Present Business

Education System .............

XII Quantitative Development of Elementary

Education ............... 66

XIII Quantitative Development of Secondary

Education ............ 67

XIV Quantitative Development of Higher Education . . . 68

XV Distribution of Students by Fields of Study--

Percentage Distribution of Students . . . . 69

XVI Drop-Out Rate During Past Twelve Years . . . . 70

XVII Gross Domestic Product by Sector of Origin,

1955 . . . . . . . . . 72

XVIII Index Numbers of Industrial Production ...... 75

XIX External Trade ............. 76

XX Distribution of Labor Force by Sector, 1966.... 78

XXI The Structure of Vietnamese Industry, 1967 ... 80

XX11. Enrollment in Secondary Education in 1964 ..... 88

XXIil Business Education as a Contributor to

Economic Development .......... 101

XXIV Business Education in Viet-Nam ........ 104

XXV Organization of Higher Business Education ..... 110

XXVI General Outline of the Proposed Business

Education System ............ . . 129 


\section{CHAPTER 1}

\section{INTRODUCTION}

\section{INTRODUCTION TO THE PROBLEM}

The success of an educational system depends on the ability of that system to answer the needs of the people as well as the needs of the nation. The goals of the country are usually reflected in its educational system.

"The policy of the Republic of Viet-Nam is to realize a system of mass and practical education." ${ }^{1}$ This means that education in Viet-Nam is not a privilege of any group, and the educational system must include practical applications. The important point is that the system has to successfully coordinate the two objectives of education: (1) the development of personal capabilities and (2) the individual's adjustment to society. Furthermore, Viet-Nam is in great need of many experts, specialists, technicians, and skilled workers who can contribute to a developing national economy. For that reason special attention should be focused on technical and vocational education to train enough technicians to answer the needs of the country.

This was identified in 1964 at the National Education Convention in the opening speech of Dr. Bui Tuong Huan, Minister of National

${ }^{1}$ Translated excerpt from "Thong-diep cua Tong-thong Viet-Nam Cong-hoa gui Quoc-dan Dong-bao ngay 6 thang 10 nam 196911 (Speech to the Vietnamese people by the President of the Republic of Viet-Nam, del ivered on October 6, 1969), mimeographed, p. 2. 
Education:

In the field of education we have only one concern-how to perfect on an emergency bas is all educational installations from the infrastructure to the superstructure, how to improve the system, how to make the programs of studies more suitable to the conditions of our nation, an agricultural developing nation which is on the way to industrialization and which needs many specialists and technicians

for its economic development ... O Our educational system is called upon to promote the people's welfare and raise their standard of living. 1

Education plays a vital role in economic and social development. The Vietnamese educational program is changing to fit the need of an emerging nation. Comprehensive education is developing. Priority is being given to technical and vocational education. ${ }^{2}$ Business education is being introduced into the pilot comprehensive high schools under an experimental program of restructure of the educational system. For these reasons, a study concerning the development of Vietnamese bus $i$ ness education is necessary to promote its development in Viet-Nam.

\section{STATEMENT OF THE PROBLEM}

This study analyzed business education in selected foreign countries and the Vietnamese educational system and its environment in order to derive a proposal for the development of business

1Translated excerpt from "Dien-van cua Giao-su Bui Tuong Huan, Tong-truong Giao-duc, Dai-dien Thu-tuong, doc tai buoi Khai-mac Dai-hoi Giao-duc Toan-quoc thang 10, 1964," Giao-duc Viet-Nam 1965 (Saigon: Nha Nghien-cuu va Ke-hoach Bo Quoc-gia Giao-duc, 1965), P. 20.

Translated excerpt from "Speech of Dr. Bui Tuong Huan, Minister of National Education, representing the Prime Minister, at the opening ceremony of the National Education Corivention, October 1964," Viet-Nam Education 1965 (Saigon: Department of Research and Planning, Ministry of Education, 1965), P. 20.

2 President of the Republic, op. cit., p. 3. 
education in Viet-Nam. In order to develop the proposal, the following questions were answered:

1. What are the principles of business education in selected foreign countries?

2. What is the profile of the present Vietnamese business education system?

3. Why is there a need for development of business education in Viet-Nam?

4. What should be the philosophy and objectives of business education in Viet-Nam, (1) at the secondary level? (2) at the university level?

5. How should the problems of organization, curriculum development, and faculty recruitment be resolved?

6. Is a business educator-training program necessary?

7. What guidelines should be recommended for the development of business education in Viet-Nam?

\section{SCOPE OF THE PROBLEM}

The study was an attempt to formulate a philosophy and objectives of business education in Viet-Nam. It also identified the basic prob-lems of organization, curriculum development, and faculty recruitment and training at the university and secondary levels.

This study could serve as a foundation for elaborating detailed business education programs. 
IV. DELIMITATIONS

The proposal dealt with general principles of development of business education in Viet-Nam. It neither set up a detailed plan nor a detailed curriculum. It only aimed to build a foundation. The proposal did not conclude how much business education or what kind of curriculum should be developed in the. Vietnamese schools. Such a specific program will require further thorough and intensive research in industrial and economic development of the nation.

\section{v. DEFINITION OF TERMS}

The terms used in this research will be interpreted according to the following definitions:

Economic independence is defined as stated in "The Postwar" Development of the Republic of Viet-Nam: Policies and Programs"l:

By economic independence we imply not an isolated and stagnating self-sufficiency, but a situation in which, in the context of its relations with southeast Asia and the rest of the world, the Vietnamese economy will continue to grow and its people to prosper on the strength of their own skills and resources without continuing dependence on concessionary aid from overseas. 1

Developing country is a nation (1) whose people are beginning to utilize available resources to increase per-capita production of goods and services, (2) which is on the way to industrialization, and (3) which is capable of a greater substantial improvement in its income level and is in process of achieving this improvement.

1Thuc, Vu Quoc and Joint Development Group, The Postwar Development of the Republic of Viet-Nam: Policies and Programs, Volume 111 (Saigon: Joint Development Group, 1969), P. 1. 
General education is defined as "a broad type of education aimed at developing attitudes, abilities, and behavior considered desirable by society but not necessarily preparing the learner for specific types of vocations or vocational pursuit."1

Vocational education refers to a "program of education below college grade organized to prepare the learner for entrance into a particular chosen vocation or to upgrade employed workers. ${ }^{2}$

Business education is "(1) that area of education which develops skills, attitudes, and understanding essential for successful direction of business relationships and (2) an area of study dealing with the principles and practices of teaching of business subjects. $1{ }^{3}$

General business education is an aspect of business education which enables the learner to understand; to appreciate, and to perform effectively the business functions of everyday living which are common to all people.

Basic business education consists of academic business subjects which provide the learner with a business background necessary for the study of specialized business fields.

Business skill courses refer to typewriting, shorthand, bus iness machines, card punching.

1 Herbert A. Tonne, "The Scope of Social Business Education," National Symposium on Socio-Bus iness Education Monograph 31 (Cincinnati: South-Western Publishing Company, 1936), p. 12.

${ }^{2}$ Carter V. Good, editor, Dictionary of Education (New York: MCGraw-Hill Book Company, 1959), P. 603.

3 lbid., p. 70. 
Baccalaureat 11 is the examination at the end of Grade 12 which qual ifies the student as a high school graduate.

Licence is a degree offered to students who have successfully completed a four-year university course.

Diploma of higher study refers to a degree which leads to a doctor's degree after completing a dissertation.

Faculty is a branch of a university which offers a specialized field of study.

Faculty of Pedagogy is a branch of a university which provides high school teacher-training.

Upper secondary or second cycle high school is a senior high school which includes Grades 10, 11, and 12 .

\section{METHODS AND PROCEDURES}

The steps followed in developing this study were:

1. A review of business education in selected foreign countries: Emphas is was placed on countries (1) which have an advanced business education system, or (2) which have an educational system close to that of Viet-Nam, or (3) which gained independence after World War 11 , or (4) which are developing. It was necessary to ascertain the philosophy, the objectives, and the organizational system of business education in these countries. These data were required to establish a plan to develop business education in Viet-Nam. Special attention was paid to the business education system in the United States which was the initiator of the comprehensive high school and possesses a welldeveloped business system. Special attention was also given to the business education system in France because the French educational 
system is similar to that of Viet-Nam. The French system was analyzed as a typical European system whose progress could help clarify the need for restructuring the Vietnamese system. The bus iness education - in developing countries was helpful because it expanded in an environment similar to that of Viet-Nam.

The review of literature on business education in countries other than Viet-Nam, from advanced industrialized countries to developing industrialized countries, showed the characteristics of business education which are widely accepted in different environments and provided samples and models that were adapted to the Viet-Nam environment.

2. An analysis of the Vietnamese educational system, especially the Vietnamese business education system and its environment. The analys is included two parts:

a. an outline of the educational system, its basic principles, and the trend and organization of vocational and technical education. Business education was described and statistical data presented which showed the achievement of the total educational system.

b. an analysis of the environment. This consisted of a review of the literature related to the Viet-Nam environment, emphasizing the characteristics of the business system, the present business situation, and the prospects of economic and industrial development. This analysis described the need for business education to train white collar workers and businessmen.

3. A proposal for development of bus iness education in Viet-Nam. This proposal is based upon the experiences of business education in 
countries other than Viet-Nam, and the analysis of the Vietnamese educational system and its environment. The above factors, especially the results of the present system of education, the deficiencies of the business system, and the needs of economic and industrial development indicated how the philosophy and objectives of business education should be organized to fit the needs of the nation. 
CHAPTER 11

\section{RELATED LITERATURE ON BUS INESS EDUCATION IN FOREIGN COUNTRIES}

\section{PHILOSOPHICAL FOUNDATIONS OF BUSINESS EDUCATION}

Educational philosophy has been influenced by many great thinkers of the past. This section will focus on those educators whose thinking changed the trend in education from formalized, lockmstep education for a select few to a more comprehensive system of education for the masses. There have been numerous movements to make education contribute more directly to the real business of living. One of the earlier American proponents of a revised, more democratized high school curriculum was Horace Mann (1796-1859). A practical man, he believed that knowledge should be useful. Mann's most outstanding contribution to education was his list of recommendations for curriculum revision. Into a formalized college-oriented educational philosophy, he injected a utilitarian concept. His two main themes were (1) that the sound judgment of citizenship must be based on knowledge of the organization of and forces within the society in which the citizen acts, and (2) that personal economic competencies were important.

Why should algebra, which not one man in a thousand ever uses in the business life, be studied by twice as many pupils as bookkeeping, which everyone, even the day laborer needs? 1

$1_{H}$. B. Good, History of American Education (New York: The MacMillan Company, 1956), p. 160 . 
These siatements, pointing out the need for developing in all students the business and economic understandings requisite to effective citizenship, represent what is known today as basic business education.

Most of Mann's views on education reflected the concepts of the Swiss educational reformer Johann Heinrich Pestalozzi (1746-1827) who pioneered the learn-by-doing theory that was to become progressive education in Europe in the nineteenth century.

In England, Spencer (1820-1903), one of the early modern educa'tional leaders, bel ieved that education should be part of living and that the curriculum should be drawn from the realm of 1 ife. In his famous essay "What Knowledge is of Most Worth?", he wrote:

In education, then, this is the question of questions, which it is high time we discussed in some methodic way. The first in importance, though the last to be considered, is the problem--how to decide among the conflicting claims of various subjects on our attention. Before there can

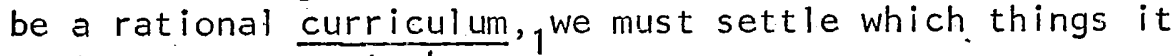
most concerns us to know.

Spencer admonished educators to build a curriculum on the basis of the relative value of knowledges. A measure of value is the first requisite. The value of each subject depends on its contribution to success in business, that is, to satisfactory living. The educator has to answer the question, "Of what use is it?"i2 And when he fails to make clear any appreciable effects which these facts can produce on human welfare, he is obliged to admit that they are

1Herbert Spencer, Education: Intel lectual, Moral and Physical (New York and London: D. Appleton and Company, 1910), Pp. 14-15.

2 lbid., p. 15 . 
comparatively valueless. He also pondered the purpose of education as

follows:

How to live?--that is the essential question for us. . . In what way to treat the body; in what way to treat the mind; in what way to manage our affairs; in what way to bring up a family; in what way to behave as a citizen; in what way to utilize all those sources of happiness which nature supplies-how to use all our faculties to the greatest advantage of ourselves and others--how to live completely? ${ }^{1}$

The concept of analyzing educational needs in terms of life needs became the pattern for building business curricula. Every statement of the purpose of education, especially of business education in recent years, is based on this idea.

Spencer also classified, in order of importance, the leading kinds of human activities as follows:

1. Those activities which directly minister to selfpreservation.

2. Those activities which, by securing the necessaries of life, indirectly minister to self-preservation.

3. Those activities which have for their end the rearing and discipline of offspring.

4. Those activities which are involved in the maintenance of proper social and political relations.

5. Those miscellaneous activities which make up the leisure part of life, devoted to the gratification of the tastes and feelings.

The activities described in No. 2 above are really vocationalpersonal business abilities and general business knowledge for everyday living. The activities described in No. 4 concern citizenship education, which is also a part of general business education.

1 lbid., p. 16.

2 lbid., pp. 13-14. 


\section{BUSINESS EDUCATION IN THE UNITED STATES}

Since 1903, the American National Education Association has included in its report a section on business education. In 1918, a Commission, The Reorganization of Secondary Education, appointed by the U.S. Bureau of Education, listed seven objectives of education in a democracy which were well-known as the "seven cardinal principles" of education. They are:

1. Health

2. Command of the fundamental processes

3. Worthy home-membership

4. Vocation

5. Citizenship

6. Worthy use of leisure

7. Ethical character. 1

The objectives--command of the fundamental processes, vocation, citizenship, and ethical character--imply socioeconomic education which is the background of basic business education. In 1938, the Educational Policies Commission, in an attempt to determine the necessary and desirable elements of information, skill, habit, interest, and attitude which would surely promote individual development and encourage a democratic way of life, stated the four objectives to guide education in American democracy. They were:

1. The objectives of self-realization

2. The objectives of human relationship

3. The objectives of economic efficiency

4. The objectives of civic responsibility ${ }^{2}$

1"Cardinal Principles of Secondary Education," United States Bureau of Education, Bulletin No. 35 (Washington, D. C.: United States Government Printing office, 1918), pp. 9-16.

2Educational Policies Commission. The Purpose of Education in American Democracy (Washington, D. C.: National Education Association, 1938), pp. 39-124. 
In presenting the four purposes of education, the Commission emphasized the interdependence of education and democracy:

Neither democracy nor real education can exist without each other... our democracy needs education. It is indeed clear that no government based on democratic principles can long endure in a nation of ignorant people. 1

Initially, business education began with a vocational objective. Over the years an additional general education objective has developed because of the need for everyone to handle his personal business affairs competently.

\section{Attacks on Business Education}

Business education in the United States, in the post-Sputnik years, has been the victim of a national anxiety--almost a guilt complex which has produced attacks on every form of non-academic education. The right of American students to choose their curriculum depending on their needs and to possess a "marketable skill" upon completion. of the secondary school has been challenged as never before in the history of American education.

Will my boy learn as much if he takes some business courses as he would if he took straight academic work? Will it help him as much in college? Will he be able to get a good job in business after high school? Is it necessary to spend so much money for education? All those new machines for office practice and that multiple-channel laboratory for shorthand-aren't these "frills" that could be dropped from the curriculum at great savings to the taxpayers? ${ }^{2}$

Business education under these attacks might have faced two "equally bleak alternatives": serving as a dumping ground for slow

1 lbid., pp. $22-23$.

2Ruth Woolschlager, "An Appraisal of Attacks on Business Education since Sputnik," The National Business Education Quarterly, Volume 30, No. 2 (Winter 1961), p. 5-21. 
learners, or going out of high school altogether. Neither of these

has happened and American business education has been progressing and growing.

If only the unable take the business courses and inefficient workers are sent to the offices of our communities, businessmen themselves will rebel and refuse to hire high school prepared people. Practically then, business will fail. If business education is removed from the high school curriculum a cardinal principle of American education will be destroyed--the right of every student to obtain at pubic expense in his own community a "marketable skill."1

In 1961, approximately 880,000 of 1,813,000 high school graduates in the United States did not go on to college, while arother group of about 900,000 dropped out of high school before graduation. It is clear that in 1961 about half of the high school population needed vocational education and that most of these students were not slow learners.

The Vocational Education Act of $1963^{2}$

The Vocational Education Act of 1963 strengthened and improved. the quality of vocational business education and expanded the vocational opportunities in the United States. This act defined four types of American vocational schools:

1. a specialized high school providing full-time vocational education.

2. a department in a high school with at least five different occupational fields.

1 lbid., P. 8.

2 United States Congressional and Administrative News 88th Congress- First Session 1963 (New York: Edward Thompson Co., 1963), Pp. 445-464. 
3. a technical school open to students who have dropped out of high school or who have completed high school.

4. a department of vocational education in two-year colleges or universities.

All types of vocational schools are operating throughout the nation. Through the Vocational Education Act of 1963, a milestone in the history of business education in the United States was reached. It authorized substantial grants to the states to assist them in maintaining, extending, and improving existing programs and in developing new programs of vocational education

Business Education in the American High School

A statement by the Policies Commission for Business and Economic Education mentioned that the purposes of business education in the high school are to develop:

1. The knowledge, attitudes, and vocational skills needed by all persons to be effective in their personal economics and in their understanding of our economic system.

2. The vocational knowledge and skills needed for initial employment and for advancement in a business career. 1

The Commission believed that business education contributes to the economic literacy of every high school student and provides an adequate program of vocational training for students who will seek business employment upon completion of high school, or a program of prevocational preparation for students who will enter colleges and un iversities.

1 Policies Commission for Business and Economic Education, "This We Believe about Business Education in the High School, "Business Education Forum, Volume 15 (May 1961), pp. 19-30. 
The economic program should help every student (1) to develop economic literacy, (2) to gain an understanding and appreciation of the national economic system, and (3) to become an intelligent consumer of goods and services.

The vocational program should include sequences of courses that adequately prepare youth for initial employment in business.

The prevocational preparation should include at least the following:

1. Provide occupational information to develop interest in bus iness life.

2. Develop understanding of economic concepts and institutions.

3. Develop computation skills, communication skills, and application techniques.

4. Provide occupational intelligence necessary for understanding business.

5. Utilize the resources of other groups. ${ }^{1}$

Because the world of work is changing, there are new implications for business education to meet the challenges of the future.

Justification for Business Subjects for the College-Bound Student

The Policies Commission for Business and Economic Education of the American National Education Association strongly urged all collegebound students in high school to give serious consideration to

1 Policies Commission for Business and Economic Education, "The Function of Prevocational Preparation in Business Education," Business Education Forum, Volume 23 (January 1969), p. 33. 
including certain business subjects in their high school program on the basis of the following justifications: 1

1. High school business subjects have personal-use values.

2. Vocational business subjects are of great value for part-time emp loyment.

3. Vocational business preparation is valuable to the college dropout. Over 50 percent of the students who enter four-year colleges today withdraw within the first two years for any of several reasons.

4. Business subjects are helpful in guidance and as a founda... tion for college business courses.

5. Business subjects help students understand the businesseconomic environment.

6. Basic business subjects teach students how to manage their personal business affairs.

A study completed in 1963 by Kennedy explored the differences in academic achievement in an undergraduate college of business of students who had a varied background in high school. The results of the study indicate that students who take high school programs that are not 1 imited to traditional subjects may succeed very well at the college level. Scholastic success depends largely upon the industry and native ability of the student--not upon any particular combination of subjects studied. ${ }^{2}$

1 Policies Commission for Business and Economic Education, "Business Education for the College Bound Student," Business Education Forum (May 1964), pp. 21-22.

${ }^{2}$ Calvin E. Kennedy, Differences in Academic Achievement in an Undergraduate College of Bus iness Among Students Having Different Backgrounds of High School Preparation, unpublished doctoral dissertation. (Lincoln: University of Nebraska). 
Professional Business Education

Professional business education is offered in regular colleges and universities. The emphasis is on education for leadership and management responsibilities, or on highly technical aspects of business. The graduate schools concentrate on the application of background knowledge, functional specialties, and managerial skills and responsibilities.

Donald K. Davis considered the task of professional business education to be essentially the communication of professional knowl.edges, attitudes and skills. He remarked that the role of business education has changed rapidly during its existence in the direction of increased usefulness, expanded purposes, and wider acceptance. The product of business education has been sought by business and government and has typically proved successful in both areas.

It is believed that this fortunate outcome is traceable to a change of focus away from vocational techniques toward a slowly broadening concept of administration. I mean by "administration" the accomplishment of the purpose of an organization by, through, and with people. The current concept of administration has unified the study of accounting, finance, marketing, and production and has given recognizable shape to business education. 1

The Davis concept emphasized the responsibility of business education to provide business and government with able men equipped to become managers or administrators. To be effective, governmental administration must draw on universities for those graduates who have achieved success in business. These people can and should assume

${ }^{1}$ Thomas H. Caroll, Bus iness Education for Competence and Responsibility (Chapel Hill: The University of North Carolina Press, 1954), p. 16. 
governmental positions of great power and influence. The difficult disciplines of economics, accounting, production, marketing, money and banking, corporate finance, personnel management, and statistics are the training ground for those who are required for an efficient government.

In the United States, business education is one of the components essential to the educational program of a democratic society. It conforms to the needs of the students, to the way of life of a progressing nation. Its objectives are general education for every student, vocational for students who need employment upon completion of high school, prevocational for college-bound students, and professional for college and university business students. Business education will provide workers and managers for business organizations, as well as for government agencies, and contribute substantially to a pool of leadership for a better world. (Table 1)

\section{BUSINESS EDUCATION IN FRANCE}

The Preamble to the Constitution of the French Republic declares that the "Nation guarantees to children and adults equal access to education, professional training and culture."1 Compulsory attendance begins after the nursery school stage and consists of five years primary education followed by four years in the first cycle of the secondary school and one year in the second cycle. From 1962 there has been a common program for the lower level secondary school

1 UNESCO, World Survey of Education, IV (New York: Unesco Publication Center, 1966), p. 465. 


\section{TABLE $\mid$}

GENERAL OUTLINE OF BUSINESS EDUCATION SYSTEM

IN THE UNITED STATESa,b

\section{HIGHER EDUCATION}

Schools of Business and Departments of Business

Education of Colleges and Universities

Professional Business

Institutions

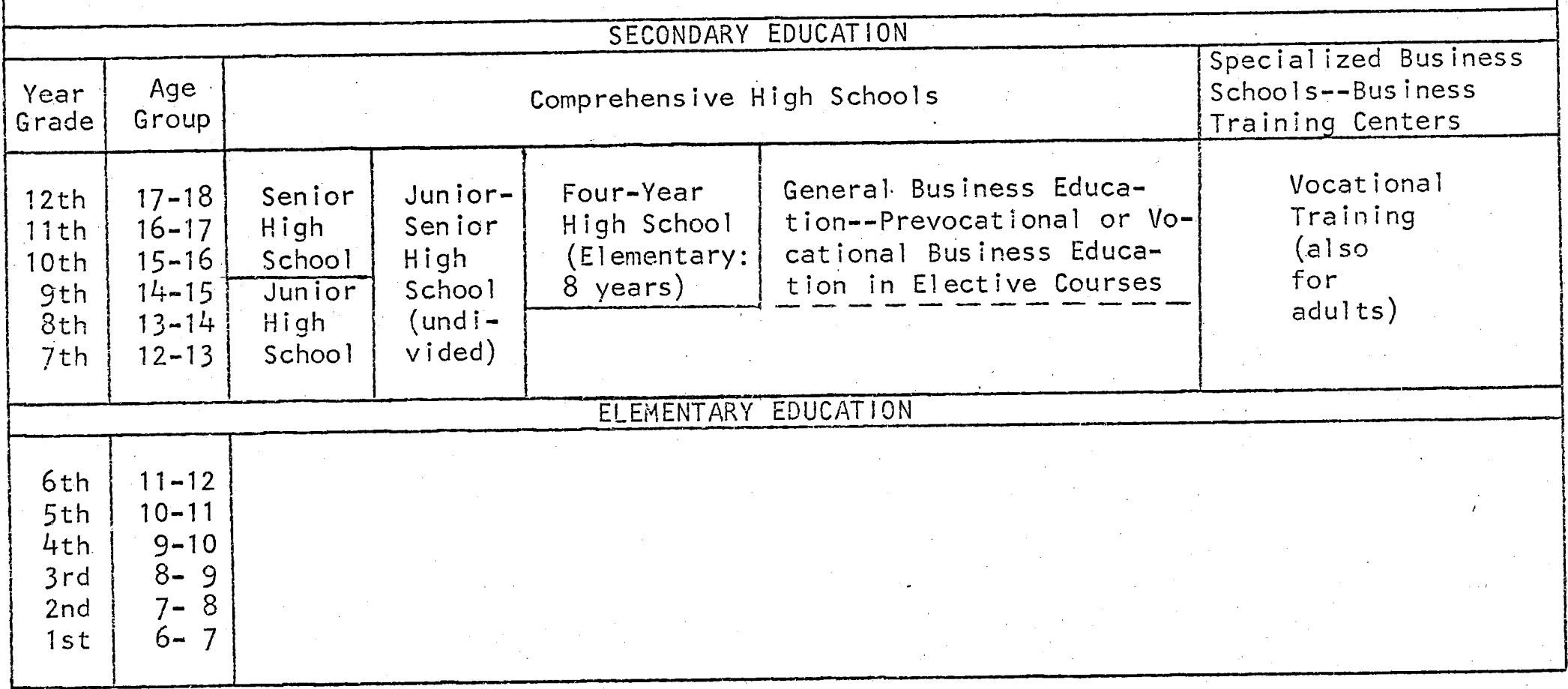

a. James B. Conant, The Comprehensive High School (New York: McGraw-Hill, 1967).

b. Unesco, World Survey of Education, IV (New York: International Documents Services, 1961), pp. 1363-1380. 
(age 13-14), 'which resembles the comprehensive program concept in the United States. Henceforth vocational education will begin at the tenth grade level (age 15) and consist of three phases. (Table 11) First Phase of Technical Business Education: Training of Employees. This phase of business education is given in free public schools or private schools recognized by the state, and in other private schools. Its goal is to widen the general education of students of at least 15 years of age who have graduated from elementary school and to teach them the basic principles and skills needed in their future professions. All schools and training centers prepare the students for the Certificate of Professional Aptitude. The following eight certificates are offered: office employee, assistantaccountant, shorthand-typist, bank employee, insurance company employee, stock exchange employee, sales assistant, and mecanography. The period of training usually lasts three years.

Intermediate Technical Bus iness Education: Training of Employees. and Second Level 0ccupations. It is organized in three types of schools:

1. Public schools: business sections of lycees and colleges, business sections of vocational and professional courses, business sections of the professional national schools.

2. Private schools recognized by the state, in particular those of the Paris Chamber of Commerce.

3. Private establishments.

1 Georges A. Male, Education in France (Washington: U. S. Department of Health, Education and Welfare, 1963), p. 121. 
TABLE II

GENERAL OUTLINE OF BUSINESS EDUCATION SYSTEM IN FRANCE $a, b$

\section{HIGHER EDUCATION}

Commercial Institutes of Faculties of Law

Higher Schools of Commerce

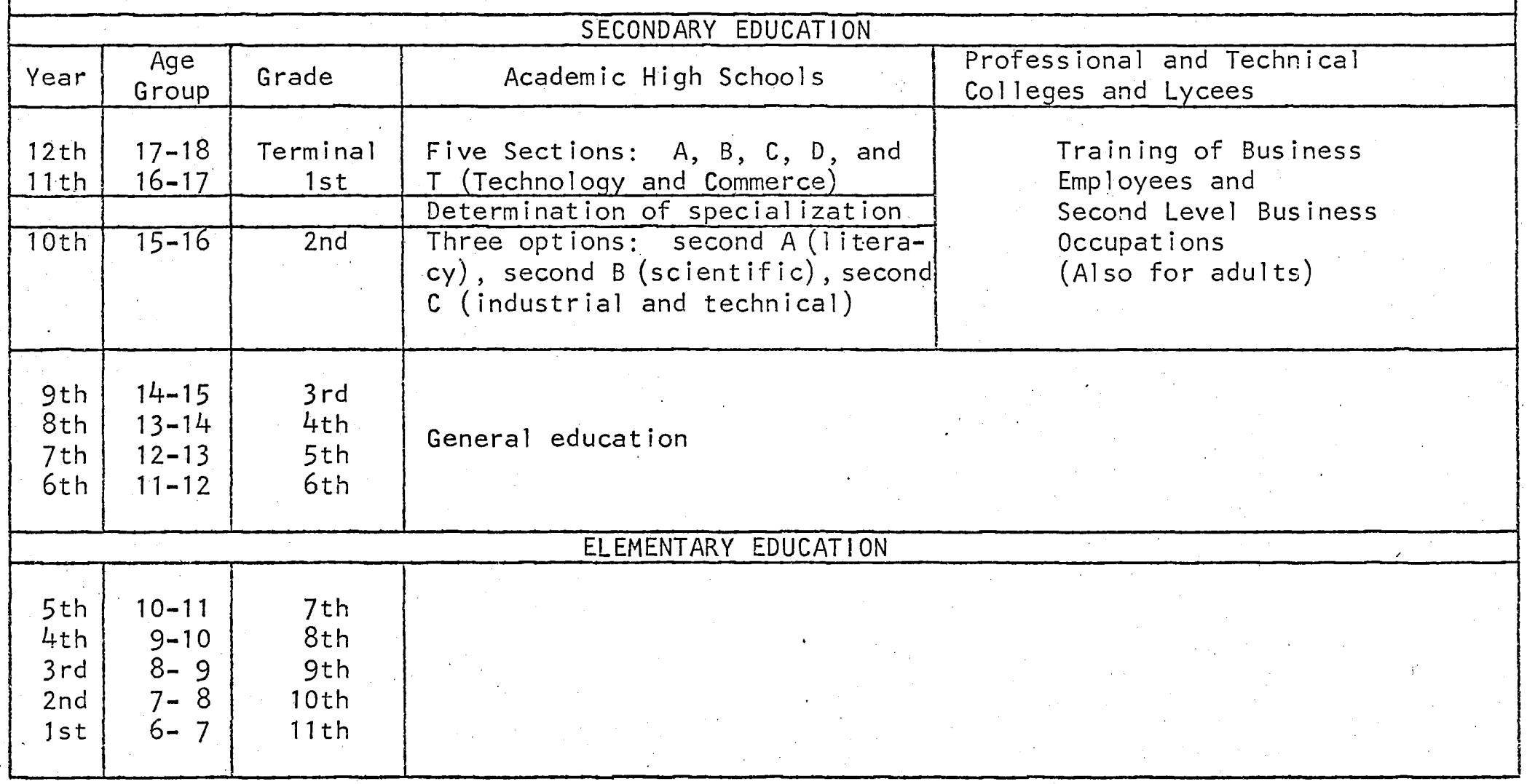

a. Unesco, International Yearbook of Education, op. cit., pp. 128-134.

b. L'Institut Pedagogique Nationale, op. cit., pp. 780-788. 
These schools give the students a broad general education together with the business course offerings. ${ }^{1}$ All prepare the students for the Certificate of Business Education First Part (Brevet d'Enseignement Commercial Premiere Partie), the majority of these schools prepare the students for the Certificate of Business Education Second Part (Brevet d'Enseignement Commercial Seconde Partie), and some of these schools prepare students for the new higher Certificate of Business Education (Brevet Superieur d'Enseignement Commercial).

The Certificate of Business Education First Part (completion of five years of elementary and six years of secondary and vocational school) qual ifies the students for the positions of accountant, business clerk, or shorthand-typist. The second certificate (completion of five years elementary and seven years of secondary and vocational) qual ifies the students for the positions of company secretary, business clerk, or accountant. The higher certificate (completion of the 13th year) qualifies the students for the upper position of accountant, secretary, or translator.

Third Phase: Higher Technical Bus iness Education. Higher business education is given in universities (Institutes of Commerce of the faculties of Law) or in private institutions of commerce (higher schools of commerce). It requires at least three years of study after the baccalaureat or after the certificate of business education, second part. Students in institutes of the faculties or in higher schools of commerce are prepared for the Diploma of Higher

${ }^{1}$ Albert Lecompte, "Business Education in France," National Education Quarterly (Spring 1960), pp. 49-55. 
Study of Commerce in accounting, secretarial work, economics, translation, statistics, or business firm management.

The higher education for the productive sector which includes higher business education is relatively unwelcome in the educational program in France. In a recent interview, President Pompidou admitted that this weakness in the education of the service sector of the French economy has resulted in a lack of competent personnel in both services and administration.

All you have to do is to see the number of students in law school or taking liberal arts. There's a traditional taste in France for work which is not directly productive. There's a job to be done to get these people into the productive sector. 1

Since 1965 the upper secondary academic schools in France have provided five sections corresponding to as many types of culture: ${ }^{2}$

1. Section A directed to literature, linguistics, and philosophical studies, and including an art option.

2. Section B directed to economics and social sciences.

3. Section $\mathrm{C}$ directed to physical sciences and mathematics.

4. Section D directed to natural sciences and mathematics.

5. Section $T$ associating scientific teaching and industrial teaching.

Students admitted to Section $B$ and Section $T$ can be prepared for the higher studies in commerce. Students entering Section $T$ are also

$1^{1}$ Frederick G. Painton, "A New Look at France, Interview with President Pompidou," U. S. News and World Report (March 2, 1970), p. 46.

${ }^{2}$ Unesco, International Yearbook of Education (Geneva: International Bureau of Education, 1966), p. 130. 
able to prepare for the higher technical baccalaureat.

1 Following is the doctrine of business education in France:

Education should not be locked into a very determined field but should be built on a general basic business education which will allow adaptation to changes.

Education should be conducted in a living and educational manner: to develop thinking, observations, initiatives, the feelings of responsibility, and intelligence is the main objective; in short, to reconcile culture and career.

Education in economics and business should be linked to reality: it should start from cases in business life, involve practices and visits to the enterprises; furthermore students should practice teamwork-a modern form, not only in executive tasks but also in executive direction. This collective thinking completes and amel iorates what concerns a decision or a planning program.

The doctrine of business education in France emphasizes the development of man during the process of vocational training, and is usually given to students of at least 15 years of age. Business education is organized in technical or professional schools at the secondary level and in universities and higher schools of commerce at the post-secondary level. The business education introduced in the upper academic high school in 1965 is for the preparation of students for higher commercial studies.

\section{BUSINESS EDUCATION IN JAPAN}

The school system in Japan is a single track system organized on the 6-3-3-4 basis: six years of primary schooling followed by

1Translated from 'L'Institut Pedagogique Nationale, Encyclopedie Pratique de l'Education en France. (National Institute of Pedagogy, Practical Encyclopedia of Education in France), (France: Ministry of National Education, 1960), p. 788. 
three years of lower secondary, three years of upper secondary, and four years of higher education.

Before World War 11, the secondary education in Japan consisted of five kinds of high schools: academic schools for boys, academic schools for girls, normal schools, technical schools, and youth schools. After World War 11, equal educational opportunity was one of the ideals underlying the recommended changes in the educational system of Japan and was incorporated by the Japanese in their Constitution and in the ir basic education laws. Since then, the Japanese have proceeded with the implementation of this ideal by consolidating the five kinds of high schools into one, developing the upper secondary schools into comprehensive schools (Table $|i|$ ), and providing coeducation at all levels. The comprehensive upper secondary schools provide general education courses and specialized vocational courses such as agriculture, commerce, industry, fishery, domestic arts, and others. 1

Business education subjects are taught at both the lower secondary education and comprehensive upper secondary education levels. At the lower secondary level (7th-9th year) the minimum school hours per week for required and optional subjects and extra curriculum activities are 30 , in which a maximum of four hours may be used for electives such as business courses.

At the comprehensive upper secondary level the 85 credits (a credit in Japan is given for one school hour a week throughout the 35-week school year) must include at least 38 hours of general

1Donald S. Anderson, Japan: Three Epochs of Modern Education (U. S. Department of Health, Education and Welfare, 1959). 
TABLE 111

GENERAL OUTLINE OF BUSINESS EDUCATION SYSTEM IN JAPANa,b

\begin{tabular}{|c|c|c|c|}
\hline \multicolumn{4}{|c|}{ HIGHER EDUCATION } \\
\hline \multicolumn{3}{|c|}{$\begin{array}{l}\text { Faculty of Economics } \\
\text { (Economics, Management and Commerce) }\end{array}$} & $\begin{array}{l}\text { Professional } \\
\text { Institutions }\end{array}$ \\
\hline \multicolumn{4}{|c|}{ SECONDARY EDUCATION } \\
\hline Year & Age Group & Upper Comprehens ive Secondary & Professional Business Schools \\
\hline \multirow[t]{2}{*}{$\begin{array}{l}12 \text { th } \\
11 \text { th } \\
10 \text { th }\end{array}$} & $\begin{array}{l}17-18 \\
16-17 \\
15-16\end{array}$ & $\begin{array}{l}38 \text { credits of general education } \\
30 \text { credits of business education } \\
9 \text { credits of physical education } \\
8 \text { elective credits }\end{array}$ & $\begin{array}{l}\text { Professional } \\
\text { Courses (also } \\
\text { for adults) }\end{array}$ \\
\hline & & \multicolumn{2}{|l|}{ Lower Secondary } \\
\hline $\begin{array}{l}9 \text { th } \\
8 \text { th } \\
7 \text { th }\end{array}$ & $\begin{array}{l}14-15 \\
13-14 \\
12-13\end{array}$ & \multicolumn{2}{|l|}{$\begin{array}{l}4 \text { hours per week } \\
\text { of vocational } \\
\text { elective subjects }\end{array}$} \\
\hline \multicolumn{4}{|c|}{ ELEMENTARY EDUCAT ION } \\
\hline $\begin{array}{l}6 \text { th } \\
5 \text { th } \\
4 \text { th } \\
3 r d \\
2 n d \\
1 s t\end{array}$ & $\begin{array}{r}11-12 \\
10-11 \\
9-10 \\
8-9 \\
7-8 \\
6-7\end{array}$ & & . \\
\hline
\end{tabular}

a. Japanese Commission for Unesco, Guide to Study in Japan, 1962.

b. Unesco, World Survey of Education, IV, op. cit., pp. 739-750. 
education, including Japanese language, algebra and geometry, science, and nine hours of health and physical training.

The vocational business student, with a requirement of 38 units of general education, and at least 30 units in business subjects plus nine units of health and physical training, has eight units for electives which may be business or other subjects. Business students who have graduated from the upper secondary school may be admitted to the Faculty of Economics, Management, and Commerce leading to the Bachelor's Degree. The graduate school consists of a two-year Master course and three-year Doctor course. 1

In Japan upper secondary schools usually receive large sums of government money for education. The Ministry of Labor cooperates with local schools and colleges in placing students in part-time and fulltime employment. Public employment security offices are set up in Tokyo and in the prefectures.

All Japan today is a school. Alert and eager to learn, the $\checkmark$ Japanese place education high in their value system and are willing to make sacrifices to obtain it. Japan is determined to modernize and to progress and this has been reflected by the Japanese educational system which aims to provide technicians for the modernization of Japan. Leaders of Japan, in their efforts to build a strong nation, have planned a utilitarian education for their people, and almost everyone goes to school. The result is that today Japan is the most impressive nation of the world in industry and commerce. To be sure, business education has contributed its part to this success.

1 Japanese Commission for Unesco, Guide to Study in Japan, 1962. 


\section{BUSINESS EDUCATION IN INDIA}

India gained its independence in 1947. In India business educam tion is given at the secondary level in the Commerce Stream of the multipurpose high schools, in commercial high schools, or in recognized commercial institutions and at the higher level in the Faculties of Arts and Commerce of the Universities or in higher technical institutions. The B.A. or B.S. of Commerce course covers three years beyond higher secondary education or pre-university level. The Master of Commerce requires two years after the bachelor's degree. (Table IV)

Business Education at the Secondary Level

The Multipurpose Secondary School. This school was established in 1955. Prior to 1955, the secondary schools in India had been largely college preparatory and academic in nature. The multipurpose school in India is based on two concepts:

1. Individual differences in interests and aptitudes.

2. The demand for many types of workers in India's developing economy.

To be a multipurpose school the high school must offer at least three of the following streams: science, humanities, fine arts, agriculture, technical, commercial, or home science. The program which is rigidly structured does not permit the students to cross over, taking one course here and there in different areas. Every student must be enrolled in the course taken by all students (language, science, mathematics, social studies, physical education, and a craft) and in the three or four classes required in his chosen stream. 
TABLE IV

GENERAL OUTLINE OF BUSINESS EDUCATION SYSTEM IN INDIAa,b

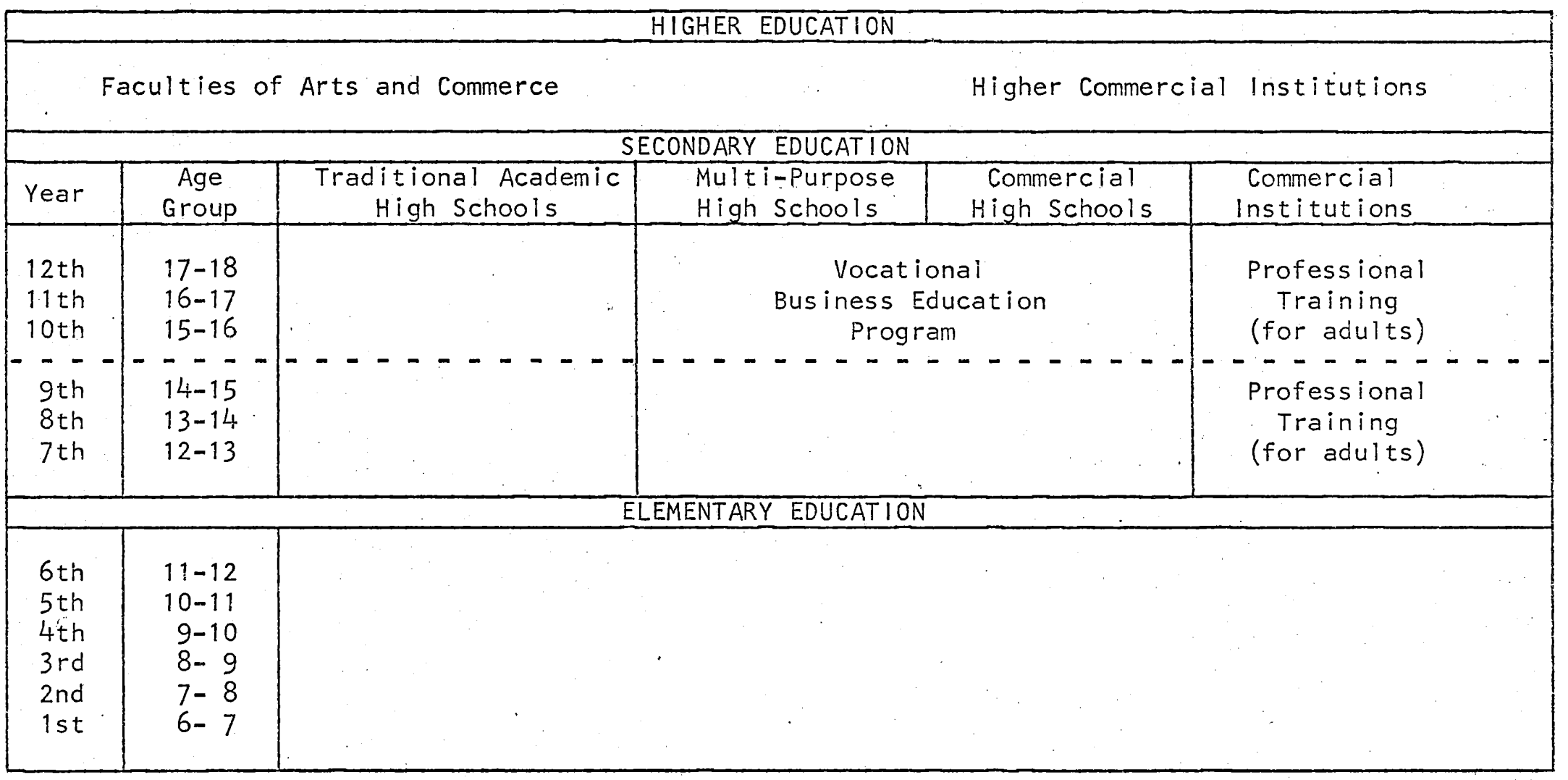

a. Unesco, World Survey of Education, IV, op. cit., pp. 649-661.

b. Frances M. Willard, The Republic of India World Education Series, 1964. 
The objective of the multipurpose school in India, as stated by the Indian Secondary Education Commission, is to train students with varied aptitudes and enable them to take up vocational pursuits at the end of the secondary level or to join technical institutions for further training.

Students in the commercial stream fall into three groups:

1. those who wish to seek office employment;

2. those who plan to initiate their own business;

3. those going on for higher education in commerce.

Commercial teachers are usually persons who have completed the Bachelor of Commerce or Bachelor of Education degree (four-year college).

The required curriculum of the commerce stream includes the basic courses such as elements of commerce (or business practice) commercial geography, economics and civics, bookkeeping, typewriting, and shorthand.

The final examination is set and administered by the state officials every spring of the year. 1

Commercial High Schools. These schools correspond to the commercial stream of the multipurpose school, preparing students for the secondary commercial certificate examination so that they are eligible for entrance into a college of arts and commerce or for initial commercial employment.

1 Inez Ray Wells, "Business Education in the Multipurpose Schools of India," National Business Education Quarterly (March 1962), pp. 5659. 
Commercial State Recognized Institutions. These institutions

prepare the students for the government commercial diploma and commercial certificate examinations which qualify them for positions in government services. The certificates are of two types--one for regular accomplishment, another for higher proficiency. The courses cover English, commercial arithmetic, elements of bookkeeping, commercial geography, methods of business, and one subject selected from shorthand, accountancy, typewriting; Indian administration, Indian banking, insurance, secretarial practice, or salesmanship.

Educational leaders in India since 1955 conceived the idea that the economic development of India would demand many kinds of workers, especially in the business area.

The business education system in India includes the commercial stream of the multipurpose schools, the commerce high schools, and the commercial state recognized institutions at the secondary level, and the Faculty of Arts and Commerce in higher education. It provides civil servants for the government, white collar workers in the business field, and professional businessmen, as well as business teachers and professors.

\section{BUSINESS EDUCATION IN INDONESIA}

Indonesia gained its independence on August 17, 1945. The current system of education in Indonesia comprises six years of universal compulsory education, two cycles of secondary education, each of three years, and three to six years to a first degree or diploma. 
Both the lower and upper secondary cycles include general and vocational/technical education, the latter covering technical, commercial, home economics, and other specializations. (Table V)

The purpose of business education in Indonesia is three-fold in character:

1. to help people become good citizens

2. to help individuals adjust to their business environment

3. to encourage business enterprise and initiative 1

Business education in Indonesia is divided into two systems:

Evening Schools of Business (Special Commercial Schools). The courses in these schools are offered especially for adults and office workers who want to improve their knowledge and opportunities for promotion in their work. Students enrolled in this program must have a certificate from the elementary school and must be at least 18 years of age. The certificate granted by the evening business school has the same value as the certificate of the junior business high school. The curriculum of the evening school consists of the following subjects: Indonesian, English, correspondence in Indonesian, correspondence in English, general business, bookkeeping, business arithmetic, algebra, economic geography, business law, shorthand, and typewriting.

Day Schools: Junior Business High Schools and Senior Business High Schools. Commercial high schools in Indonesia correspond to the general secondary school.

The Junior Business High School offers a three-year course and requires the certificate of the elementary school as a prerequisite;

1 Soemarsono, "Business Education in Indonesia," National Bus iness Education Quarterly, Volume 28, No. 3 (Spring 1960), pp. 41-44. 


\section{TABLE V}

GENERAL OUTLINE OF BUSINESS EDUCATION SYSTEM IN INDONESIAa, b

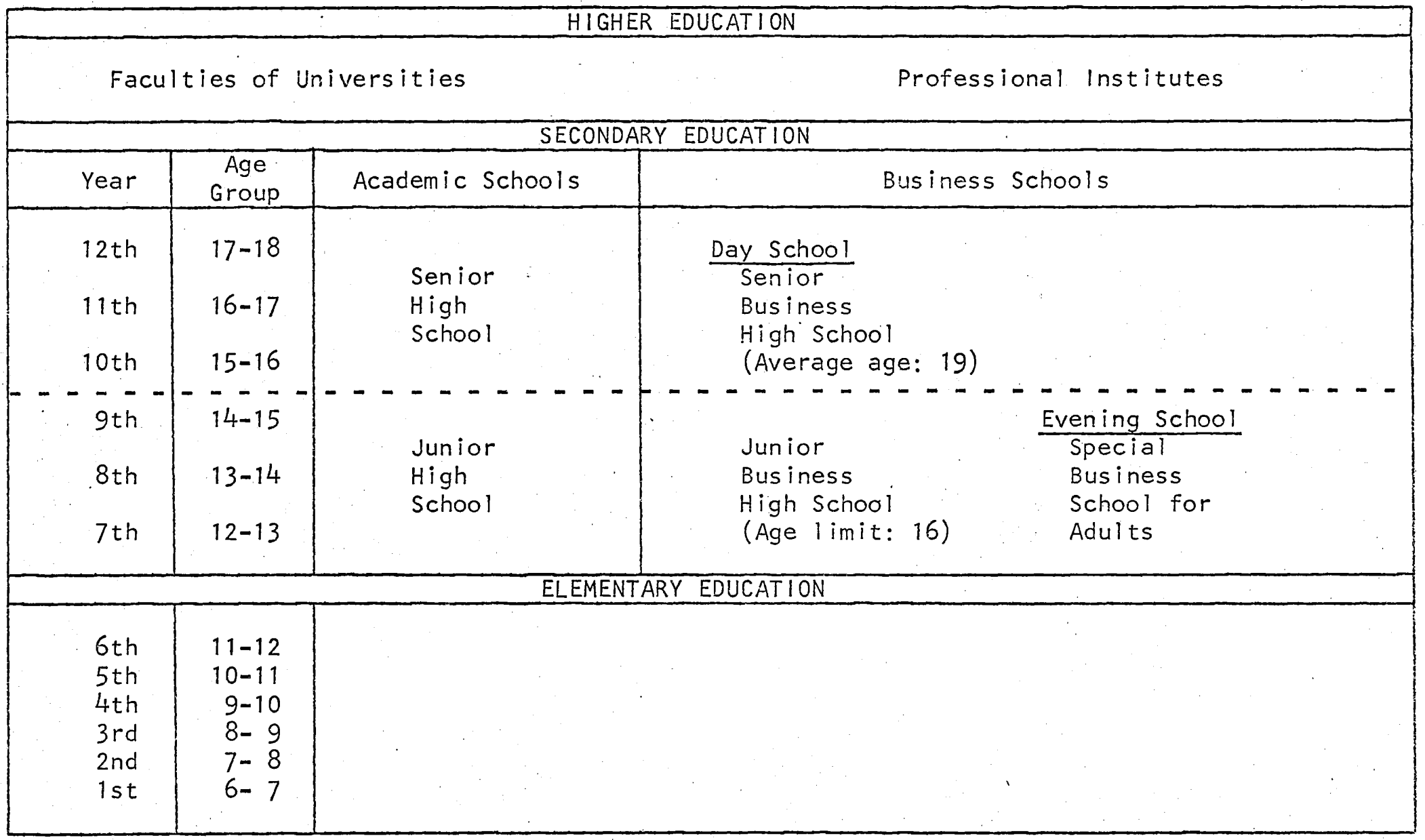

a. Unesco, World Survey of Education, IV, op. cit, pp. 662-671.

b. Soemarsono, op. cit., pp. 41-44. 
the age limit is 16 . The curriculum is broader than that of the evening school. It includes history, physics, salesmanship, drawing, and gymnastics, in addition to business courses. After passing the final examination, the students receive a certificate and may look for a job or obtain admittance to the Senior Business High School. Every year about 70 percent of the graduates go to the Senior Business High School; the other 30 percent look for jobs as clerical workers or initiate their own business enterprises.

The Senior Business High School also offers a three-year course to students who have a certificate from either a junior general or junior vocational high school. The curriculum of the Senior Business High School covers a broader area of subjects including business organization, algebra, economics, and chemistry. These graduates are paid well in Indonesia. The Senior Business High School is a terminal secondary school and its certificate does not qualify a student to enter a university or a college.

The teacher education institutes offer specialization in certain areas such as economics and administration. A certificate of comple.tion of the three-year course program is a prerequisite for an advanced two-year program.

Indonesia, which considers business education to be a good contribution to the growth and development of youth, has organized a system of separate commercial high schools at the secondary level. It also has sent educators to various countries to study foreign systems and to. bring back suggestions for improvements. 


\section{BUSINESS EDUCATION IN THAILAND}

The structure of the Thai system of education has the four conventional levels: premprimary, elementary, secondary, and higher education (Table V/1).

Since 1961 a combination of general academic education and basic vocational knowledge and skills has been emphasized. In the upper primary school (5th- 7 th year) the main emphasis is on practical arts education, to which six to eight hours a week are allotted, and the introduction of English. The revised secondary education program has two branches: the general academic branch and the vocational training branch. (The general academic branch stresses acadenic instruction and provides the foundation for further studies in higher education. 1 In the general academic branch of the secondary school, four to six hours are devoted to practical arts. In the vocational training branch 17 hours out of the total of 35 hours a week are devoted to vocational and related subjacts. In the upper secondary vocational school, 18 of the 30 instructional hours are reserved for vocational subjects. - Besides the business education stream at high school, Thai students can enter the School of Comnerce after the lower secondary school (11th year). In the three-year language course at the School of Commerce, the subjects taught are French, English, Thai, typing, English and Thai shorthand, and history and geography. In the three-year secretarial course, the subjects are English. Thai typing, Thai and English stenography, bookkeeping, and commercial law. 
TABLE VI

GENERAL OUTLINE OF BUSINESS EDUCATION SYSTEM IN THAILANDa

\begin{tabular}{|c|c|c|c|c|}
\hline \multicolumn{5}{|c|}{ HIGHER EDUCATION } \\
\hline \multicolumn{5}{|c|}{$\begin{array}{l}\text { Faculty of Commerce and Accounting } \\
\text { (Commerce, Accounting, Economics, Statistics) }\end{array}$} \\
\hline \multicolumn{5}{|c|}{ SECONDARY EDUCAT ION } \\
\hline Year & $\begin{array}{l}\text { Age } \\
\text { Group }\end{array}$ & Academic & Vocational & Professional Schools for Adults \\
\hline $\begin{array}{c}12 \text { th } \\
11 \text { th } \\
---- \\
10 t h \\
9 t h \\
8 \text { th }\end{array}$ & $\begin{array}{r}17-18 \\
16-17 \\
---- \\
15-16 \\
14-15 \\
13-14\end{array}$ & $\begin{array}{l}\text { Bus iness Education } \\
4-6 \text { hours per week } \\
4-6 \text { hours per week }\end{array}$ & $\begin{array}{l}\text { Bus iness Education } \\
17 \text { hours per week } \\
18 \text { hours per week }\end{array}$ & $\begin{array}{l}\text { 3-year secretarial course } \\
\text { 3-year language course } \\
\text { 2-year clerical course } \ldots \ldots \\
\text { Vocational Training. }\end{array}$ \\
\hline \multicolumn{5}{|c|}{ ELEMENTARY EDUCAT ION } \\
\hline $\begin{array}{l}7 \text { th } \\
6 \text { th } \\
5 \text { th } \\
---- \\
4 \text { th } \\
3 \text { rd } \\
2 n d \\
1 \text { st }\end{array}$ & $\begin{array}{r}12-13 \\
11-12 \\
10-11 \\
---- \\
-9-10 \\
8-9 \\
7-8 \\
6-7\end{array}$ & 6 to 8 hours a & 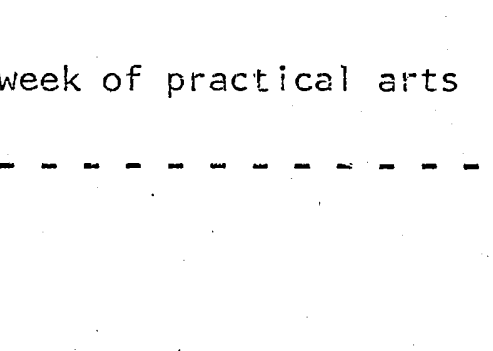 & $------\cdots---\cdots$ \\
\hline
\end{tabular}

a. Unesco, World Survey of Education, IV, op. cit., pp. 1070-1078. 
- The two-year clerical course includes English, Thai typing, Thai shorthand, a little bookkeeping, and commercial law. Graduates from the high school vocational stream or from the three-year course at the School of Commerce can be admitted to the higher institutions of commerce (Faculty of Commerce and Accounting) or get jobs in bus iness or government offices.

Thailand's present vocational system including business education does not attract the most capable students. The reason is that "in the hierarchy of educational prestige it has a low position and is selected only after all other educational doors have been ciosed." 1 )

The Faculty of Commerce and Accounting at the University has four Departments: Commerce, Accounting, Economics and Statistics. Its main objective is to prepare individuals to form the foundation of a managerial class in Thailand. ${ }^{2}$

\section{BUSINESS EDUCATION AND THE COMPREHENSIVE HIGH SCHOOL}

In the United States, the high schools are of two categories: specialized high schools usually found in a number of large cities and the comprehensive schools in communities of all sizes. The comprehensive school has a program which corresponds to the educational needs of all youth of the community. Almost all of them offer business education in elective subjects. Pupils pursue both vocational

1Hugh H. Smythe and Nibondh Sasidhorn, "Educational Planning in Thailand," Comparative Education Review (June 1964), p. 37.

${ }^{2}$ Amer ican University, Area Handbook for Thailand (Washington, D. C.: U. S. Department of State, 1966). 
and academic goals in the same school.

It is called comprehensive because it offers, under one administration and under one roof, secondary education for almost all the school age children of one town or neighborhood. It is responsible for educating the boy who will be an atomic scientist and the girl who will marry at eighteen; the prospective captain of a ship and the future captain of industry. . . It is responsible, in sum, for providing good and appropriate education, both academic and vocational.

In England, a comprehensive school aims to serve the needs of all children of secondary school age in the area and provide for them "opportunities for education according to their ages, aptitudes, and abilities. ${ }^{2}$ A comprehensive high school is intended to provide all the secondary education needed by the children but without being organized in clearly defined sides or streams.

Recently there has been a tendency toward a multi-track system in the American comprehensive school.

We seem to be moving toward differentiation of groups by establishing special schools and by sharpening the difference between academic and vocational curricula in our comprehensive high schools. This trend has been accentuated by the current feeling that we need to raise the quality of our high school work for students who will go to college. 3

Every comprehensive high school or multi-track high school should provide instruction in several vocational fields, as well as a diversified 1 ist of academic objectives. To meet such requirements the

1 James B. Conant, The Comprehens ive High School (New York: McGraw-Hill Book Company, 1967), P. 3 .

2Alwyn Thomas, "Maesydderwen Comprehensive School," Richard E. Gross, editor, British Secondary Education (London: Oxford University Press, 1965), pp. 446-468.

3 Henry H. Kronenberg and Rudyard K. Bent, Principles of Secondary Education (New York: McGraw-Hill Book Company, 1966), p. 113. 
school must have a large staff and suitable facilities, which means much money.

The arguments most frequently put forth against the comprehensive school are:

1. The school is too large and too unwieldy.

2. The development of the comprehensive school means the destruction of the existing academic school.

3. The bright pupils will suffer in a comprehensive school.

4. Educating all pupils in one school would lead to a general lowering of educational standards.

5. The comprehensive school often lacks sufficient degreed staff and important facilities. 1

Those who favor the comprehensive school usually give the following reasons:

1. It is wrong to segregate children at the age of eleven and to educate them in different schools.

2. There is ease of transference in the comprehensive school which is quite unattainable in separate schools.

3. The specialized schools lessen the value of cultural training by concentrating on narrow, vocational, bread-and-butter type of training.

4. The specialized schools develop class-consciousness.

5. The specialized schools hasten a premature choice of vocation and the decision as to education beyond the high school. ${ }^{2}$

- 1Gordon Williams, "Duffryn High School" British Secondary Education (London: Oxford University Press, 1965), pp. 446-468.

2 Ibid. 
However there is a reciprocal relationship between schools and the political, social, and economic order of a country. This determines which type of school is suitable for an area or a nation.

In England there is a separate vocational school called "the modern high school." The primary purpose of this school is to develop appropriate types of vocational education for non-scholar students. However, attention is also given to the minority of able students who may be discovered. The modern secondary school which can be considered a comprehensive vocational high school has developed programs of superior worth for vocational pupils who stand on an equal footing with students from other high schools. It answers the demand for new skills and training brought about by economic and occupational changes which the traditional system of education is ill-equipped to satisfy? It also has the effect of "reconciling an educational system based on the premises of equality and the provisions of 1 iberal education with the realities of occupational stratification." 1

In Germany the comprehensive education system is being planned for the seventies:

Traditional school forms will be first enriched and later gradually replaced by the testing and introduction of comprehensive schools. 2

The vocational education will begin at the eleventh year of schooling:

When the child has been at school for ten years he takes the first half of his school-leaving certificate. Then his way leads either to education oriented around his future

1William Taylor, The Secondary Modern School (London: Faber and Faber, 1963), p. 14.

${ }^{2} \mathrm{Hildegard} \mathrm{Hamm-Brucher,} \mathrm{"Changes} \mathrm{Planned} \mathrm{in} \mathrm{the} \mathrm{Education} \mathrm{System}$ of the Seventies,". The German Tribune (March 10, 1970), p. 8. 
profession, to the outside world and his chosen career, or to the two or three years in the sixth form of the secondary stage. 1

The whole concept of comprehensive education in Germany is being included in a National Education Plan, and will be followed by a National Education Budget.

\section{CHARACTERISTICS OF BUSINESS EDUCATION \\ IN COUNTRIES OTHER THAN VIETNAM}

The review of 1 iterature on business education in the United States, France, Japan, Indonesia, India, and Thailand has revealed the following characteristics of business education:

\section{Philosophy and Objectives}

1. Business education is one of the components of an educational program in a democratic society.

- 2. The objectives of business education are general education for all students, vocational for students who need employment upon completion of high school, prevocational for college-bound students, and professional for college and university business students.

3. Intelligence is also a main objective of business education.

4. Education in economics and business should be linked to reality.

5. Business education helps people to become good citizens, helps individuals adjust to their business environment, and helps encourage business enterprise and initiative.

1 lbid., P. 8. 
6. Business education supplies workers needed in the business areas of the national economy.

7. The teaching of business education in the comprehensive school is based upon the ideal of equal opportunity.

Organization, Methods and Curriculum

1. Specialized business schools exist in most countries.

2. In the United States business subjects are offered most frequently in the comprehensive high schools.

3. In France, Japan, Thailand, and India a number of high schools inciude a business education stream.

4. In most countries the vocational student is over 15 and has completed the lower secondary education.

5. Business education in specialized business schools is usually a strong program leading to a profession.

6. Business education at higher levels is offered by a university faculty or a higher business institution.

7. Business education should be built on a basic business background which will allow adaptation to changes.

8. Business education should reconcile culture and career.

9. Business subjects offered in high schools usually are: typewriting, bookkeeping, business arithmetic, general business, economic geography, shorthand, salesmanship, business correspondence, economics, and business law. 
Output of Business Education

Business education provides practical intellectuals such as managers and administrators, technicians, supervisors, secretaries, clerks, etc. 
CHAPTER 111

\section{ANALYSIS OF THE VIETNAMESE EDUCATIONAL SYSTEM AND ITS ENVIRONMENT}

1. THE EDUCATIONAL SYSTEM

\section{Organization}

Viet-Nam, since the recovery of independence in 1945, has adapted the educational system to changed circumstances and has kept it in harmony with the aspirations of the national genius and the exigencies of the modern times. The educational system in Viet-Nam is humanistic, nationally centered, and open to all cultural influences.

Education is compulsory for all children between the ages of six and 14. Primary education of five years is followed by seven years of secondary education which includes two cycles of four and three years, respectively. The first cycle is the same for all pupils but the second is divided into four sections, emphasizing modern languages, classical languages, mathematics, or sciences. The first cycle is designed to provide students who leave school after obtaining the Certificate of the First Secondary Cycle with a basic education. The purpose of the second cycle is mainly to provide thorough preparation for higher education. Both cycles may be terminal as well as preparatory, and include general, technical, craft, agriculture and forestry, fine arts, and music courses. The second cycle is divided into two parts, the first two years (10th and 11 th grade) leading to the first 
Baccalaureat in academic and technical fields, and the third year to the full Baccalaureat. In December 1965, the Department of National Education decided to abolish the examination for the first part of the Baccalaureat.

In 1968 under an experimental program to reorganize the educational. system, eleven high schools became comprehensive pilot schools where general and vocational education were offered under the same school roof. 1

In 1969 a degree promulgated by the President of the Republic reorganized the general elementary and secondary education into a single continual twelve-year school system. ${ }^{2}$

The Baccalaureat is an entrance requirement to an institution of higher education. It is generally during the second cycle high school that pupils are guided toward one of the following institutions: Faculty of Liberal Arts, Faculty of Law, Faculty of Medicine, Faculty of Pharmacy, Faculty of Dentistry, Faculty of Sciences, Faculty of Pedagogy, Higher School of Architecture, the National College of Agriculture, Forestry and Husbandry, the National Institute of Administration, or the National Technical Education Center which has four constituent schools: the School of Civil Engineering, the Technical Engineering School, the Industrial Engineering School, and the Merchant Marine School.

Higher education extends over a minimum of four years, with the exception of five years in pharmacy, six years in architecture, and

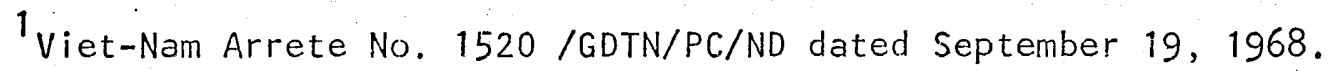
2viet-Nam Decree No. 660-TT/SL dated December 1, 1969. 
seven in medicine. Degrees offered are Licence, Diploma of Engineering, Diploma of Higher Study, and Doctor's Degree (Table VII).

Basic Principles of the National Education in Viet-Nam

Education in Viet-Nam follows these basic principles:

1. Education in Viet-Nam must be a humanist education respecting the sacred value of man, regarding man as an end in himself, and aiming at the full development of man.

2. Education in Viet-Nam is a national education respecting the traditional values, assuring the continuity of man with his national environments, such as family, profession, country, and safeguarding the nation, its prosperity, and the collective promotion of the people.

3. Education in Viet-Nam must be open-minded, respecting the scientific spirit, aiming at the development of the social and democratic spirit, and welcoming all true cultural values in the world. 1

Technical and Vocational Education

The development of technical and vocational education in Viet-Nam began in 1920 with the organization of technical training. In 1939 liaison was made between technical training and industry with the appointment of the Head of Industry and Armament as technical advisor to the Director General of Education. In 1940 technical training was encouraged by the formation of a standing committee on industrial training, which included employers. Accelerated apprenticeship courses

1 Department of National Education, Secondary Curriculum (Saigon: Department of National Education, 1959), p. 9. 


\section{TABLE VII}

GENERAL OUTLINE OF THE VIETNAMESE EDUCATIONAL SYSTEM

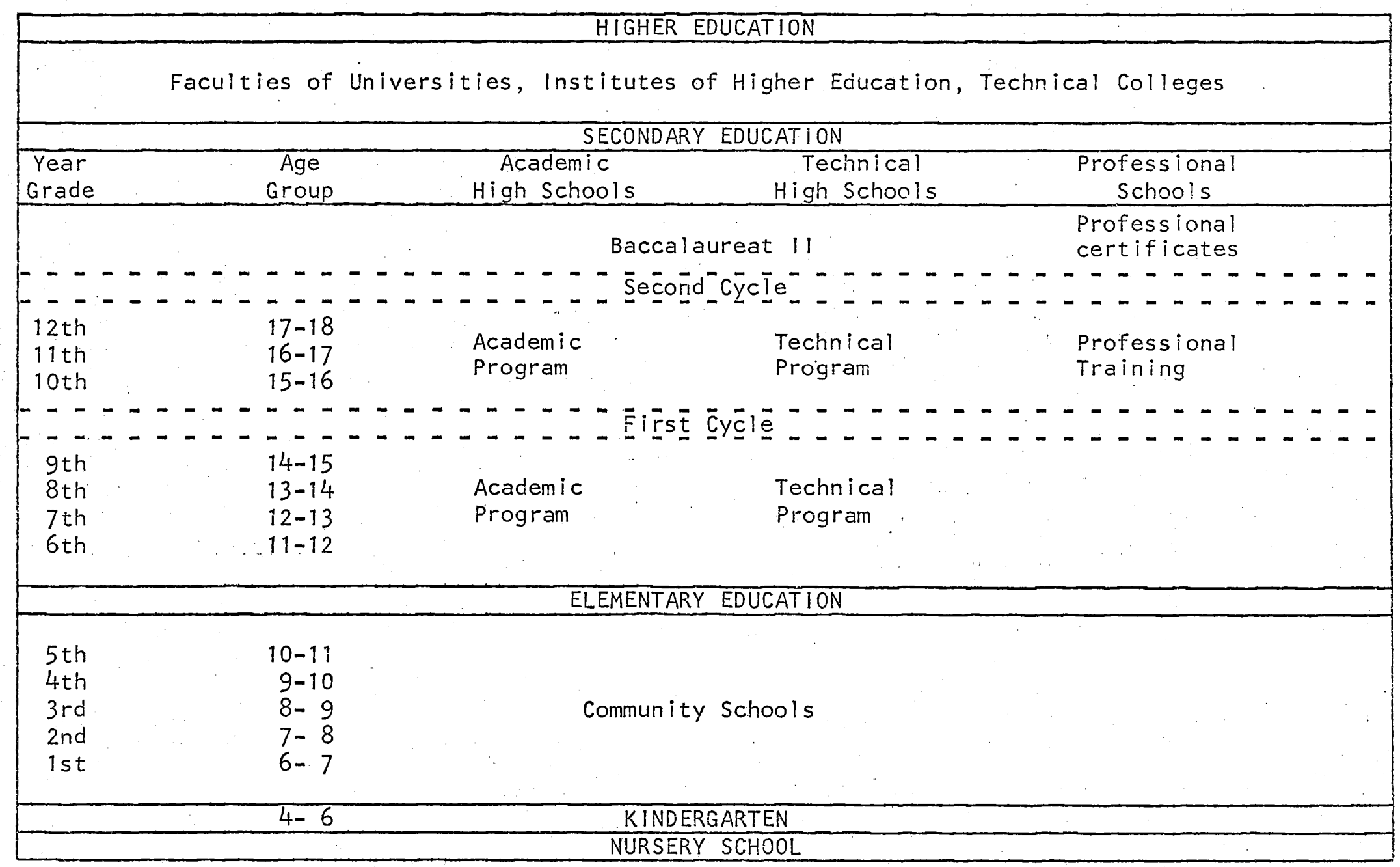


began to develop at the same time and many special sections were set up. In 1941 curricula began to be standardized and in 1944 a technical education inspectorate was organized. During World War 11 , when relations between Viet-Nam and foreign countries were interrupted, Viet-Nam manufactured locally a number of consumer goods it needed. This situation proved favorable to the development of vocational and technical training.

The second stage of vocational and technical education opened in 1955 when the Department of National Education of the Republic of Viet-Nam undertook a complete revision of vocational and technical training which involved re-opening existing institutions, informing the public of the necessity of promoting vocational and technical training, recruiting new teachers, and drafting a new staff statute so the teachers' working conditions would compare favorably with those of technicians in private industry. A Directorate of Vocational Education and Fine Arts was set up and put under the direct control of the Department of National Education.

\section{Business Education}

The first school of commerce was founded in Hanoi in 1917 . It was a constituent school of the Indochinese University. ${ }^{1}$ In 1956 the National School of Commerce was founded in Saigon. Today in the Republic of Viet-Nam secondary business education is offered by the unique National School of Commerce for adults, and through private

\section{Ministry of Education, Saigon University Bullet in (Saigon:} Ministry of Education, University of Saigon, Rectorate, 1966), p. 11. 
institutions. The Faculty of Political and Business Administration of the Da-Lat University offers a four-year course of business education leading to the Licence of Business Administration. The Faculties of Law of the Universities include a number of business subjects in the curriculum while the National Institute of Administration provides business courses related to government administration.

Since 1966 few business subjects have been offered in the demonstration and comprehensive pilot high schools and those which are given are on an unofficial, voluntary, non-credit basis, and are taught by untrained teachers.

Secondary Business Education for Adults.

The National School of Commerce. The National School of Commerce was placed under the control of the Directorate of Vocational Education and Fine Arts. It is an upper secondary vocational school.

The National School of Commerce provides adults from 18 to 25 years of age with training in technical, economic, legal, and social questions that is indispensable in civil services, commerce, industry, and banks.

Students are recruited by competitive examination from those who hold the Certificate of the First Cycle High School and a tenth-grade transcript. Every year about one quarter of the total number of students is admitted without sitting for the examination. These are secretaries in national services who hold the same certificate as those recruited by examination and who have been sent to the school by their offices. 
The course covers three years and leads to the Certificate of Commercial Studies (approximately equal to the Baccalaureat in status when working in the government office). The program is arranged in such a way that, after the initial period of probation for gaining experiences, graduates are in a position to rise to managerial posts. A number of top graduates each year have the option of entering the administration.

The three-year curriculum includes Vietnamese, English, French, typing, shorthand, accounting, practical business, economics, financial mathematics, advertising and purchasing, economic geography, business law, office education, banking, electronic computer, etc. (Table VIII). Private Business Schools. Most large cities in Viet-Nam have private business education institutions which prepare adult students to be typists, accountants, secretaries, secretary-typists, shorthand-typists, or card-punchers. Students who pass the examination for secretary-typists, administered every year by the Department of National Education, are qual ified for a position of secretary-typist in government or private offices. The period of training and the curriculum differ from one institution to another and no standard is required. Some institutions offer day classes as well as evening classes. Most of the students take only one course, specializing in typing, shorthand, accounting, or translating, etc., and usually get a certificate after three to six months of training. With this certificate they can seek temporary employment during war time. In recent years enrollments of private business schools have increased due to 
TABLE VIII

THREE-YEAR CURRICULIJM OF THE NATIONAL SCHOOL OF COMMERCE

First Year

Second Year

\begin{tabular}{lllr} 
English & 5 & English & 5 \\
French & 5 & French & 5 \\
Vietnamese & 2 & Vietnamese & 2 \\
Accounting & 6 & Accounting & 6 \\
Typing & 6 & Typing & 4 \\
Practical Business & 2 & Shorthand & 2 \\
Economics & 2 & Economics & 2 \\
Financial Mathematics & 2 & Financial Mathematics & 2 \\
Advertisement and & 2 & Navigation Law & 2 \\
Purchasing & 2 & Business Law & 2 \\
Economic Geography & 2 & Labor Law & 2 \\
Civilian Law & Statistics & 2 \\
Total hours per week & 36 & Electronic Computer & 2 \\
& & Office Machines & 2 \\
\hline
\end{tabular}

Third Year

$\begin{array}{ll}\text { English } & 6 \\ \text { French } & 6 \\ \text { Vietnamese } & 2 \\ \text { Accounting } & 6 \\ \text { Financial Mathematics } & 2 \\ \text { Banking } & 3 \\ \text { Home Trade } & 2 \\ \text { Foreign Trade } & 2 \\ \text { Insurance } & 2 \\ \text { Taxation } & 6 \\ \text { Tax Customs } & 2 \\ \text { Office Machines } & 2 \\ & \\ \text { Total hours per week } & 41\end{array}$

Note: The program will be modified according to the changing subject matter areas needed by the country and to student needs.

a. Department of National Education, Directorate of Technical and Vocational Education, The National School of Commerce (Saigon: Department of National Education, 1969), p: 33. 
the great demand for white collar workers in government offices and in offices of local and foreign companies.

Higher Education in Business.

Faculty of Political and Business Administration. The University of Da-Lat, a private institution, opened a Faculty of Political and Business Administration in 1964. The entrance requirement is the Baccalaureat 11 .

The four-year course cons ists of two 2-year stages. The first stage is for general education and orientation. The second stage provides courses in the student's chosen major field. At the beginning of the third year, students may choose either the political section or the business section. In the fourth year, students specialize in one area of the major field. Business students have the option of either economics and finance or industrial management. During the first three years students attend school in Da-Lat. In the fourth year all classes and seminars are held in Saigon. During the first three years the curriculum includes foreign languages, general education, and theories and principles of the major field subjects; the last year in Saigon students learn specialized techniques, practices, abilities of research, and understandings of the related national environment. 1

The program of study is divided into 64 units, a unit being defined as 30 class hours (Table IX and Table $X$ ). School attendance is compulsory. Students must complete 16 units each school year to

1University of Da-Lat, Faculty of Political and Business Administration, Guide to Study in the Faculty of Political and Bus iness. Administration. (Da-Lat: University of Da-Lat, 1970), 15 pages. 
TABLE IX

GENERAL OUTLINE OF THE FOUR-YEAR PROGRAM AT THE FACULTY OF POLITICAL AND BUSINESS ADMINISTRATIONa

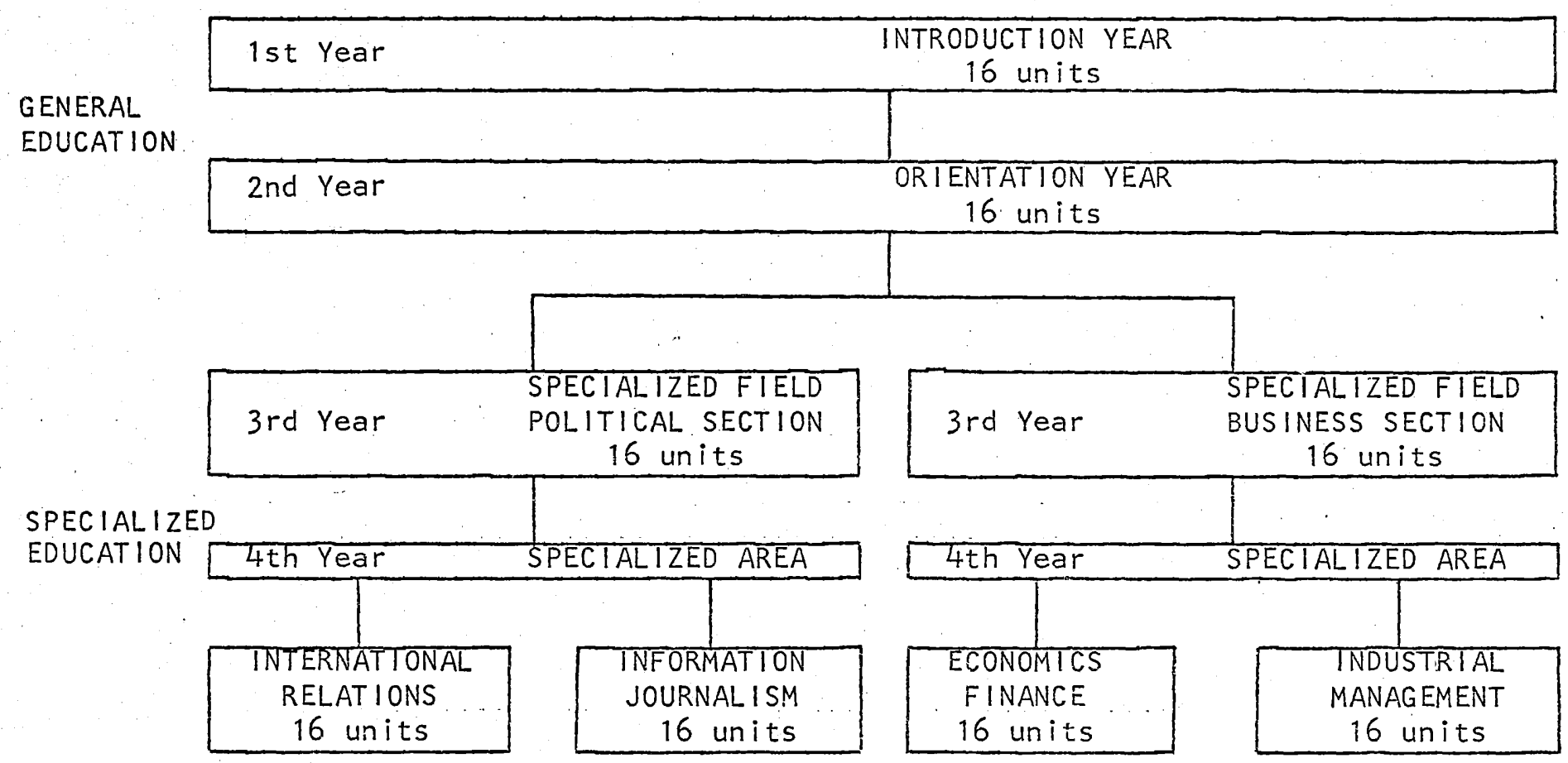

a. University of Da-Lat, op. cit., p. 4. 
TABLE $X$

CURRICULUM OF THE BUSINESS SECTION OF

THE FACULTY OF POLITICAL AND

BUSINESS ADMINISTRATION

\section{Introduction Year}

English

Literature and Writing

120 hours

History of World Civilization

60

Introduction to Political Sciences

60

Introduction to Economics

60

Introduction to Management

60

Financial Mathematics

60

Introduction to Social Sciences

60

Introduction to Law

30

30

$\overline{540}$ hours

\section{Orientation Year}

English

Conferences and Seminars

120 hours

History of Contemporary Politics

60

60

General Economic Geography

60

Principles of Economics

60

Publ ic Administration

60

Personnel Management

30

Elementary Statistics

30

Methods of Social Sciences

30

History of Social Events

30

540 hours

Third Year--Business Major

Engl ish

Government

120 hours

Viet-Nam Economy

60

60

Social Relations

30

Personnel Management

30

Economic Administration

60

Principles of Management

60

Industrial Relations

60

Industrial Statistics

30

Public Finance

30

$\overline{540}$ hours

a. University of Da-Lat, op. cit., pp. 6-9. 
Fourth Year--Special ized Industrial Management

English

Research for Industrial Projects

Production Management I

Production Management 11

Marketing Research

Distribution Research

Transportation Distribution

Managerial Accounting

Research on Industrial Management.

Seminar on Industrial Management
60 hours

30

30

30

30

30

30

30

120

120

$\overline{540}$ hours

Fourth Year---Special ized Economics and Finance

English

Finance 1: Public Expenditures

Finance 1I: National Income

Foreign Economic Aids

Money and Banking

Banking Operations

Money Exchange Institutions

Government and Business

Corporate Finance Management

Research on Economics and Finance

Seminar on Economics and Finance
60 hours

30

30

30

30

30

30

30

30

120

120

$\overline{540}$ hours 
be allowed to continue. An examination is given at the end of each unit. The scores range from one to 20 , and the average score for all units must be ten with no score less than six in order to pass. Students who get an average score above six but less than ten must take all units of the examination with a score under ten a second time after the summer vacation.

The students who satisfactorily complete 64 units are awarded the Licence of Political and Business Administration with the major field mentioned. This degree is equivalent to any Licence's degree offered by a state university in status and it is recognized by the government.

During the last two years there were 395 graduates from the Faculty of Political and Business Administration. They are all now working in the Vietnamese armed forces, in government enterprises, or in private companies. 1

The University of Da-Lat with its Faculty of Political and Business Administration has made an important contribution to the development of higher business education in Viet-Nam.

The National Institute of Administration. In 1952 the Da-Lat National School of Administration was established to train high level career administrators. At first the school was directly under the Department of National Education, but in April 1954 it was placed under the direction of the Prime Minister.

${ }^{1}$ Tran-Long, Dean of the Faculty of Political and Business Administration, Letter No. 229-CTKD/KT dated February 17, 1970 in reply to the letter of the writer dated February 1, 1970. 
In August 1955 the Da-Lat National School of Administration was transferred to Saigon and became the National Institute of Administration.

The objectives of the National Institute of Administration are to provide training for administrators and supervisors of government offices, in-service training, and research on administrative organization and modernization of office procedures.

The training programs of the Institute are of four levels: graduate, administrative generalist, head clerk, and administrative capacity.

Graduate studies: The graduate section includes three fields of specialization: general administration, economics and finance, and foreign affairs. The period of study for the students of the graduate division is two years including one year of practice in a public office or private enterprise and one year of attending classes and seminars at the Institute.

Students of the foreign affairs branch may be sent to do practice work in Vietnamese embassies in foreign countries. Subjects required of all students in the three divisions are Vietnamese culture, research techniques, enterprise, and modern techniques of administration. Subjects required of students of the economics and finance division are commercial accounting, statistics and mathematics for business, finance, business law, national accounting, agricultural economy, and law and legal research.

To be admitted to the graduate level students must hold a licence's degree and pass the entrance examination. Students must 
submit a thesis on a subject relating to their field of work and pass the graduation examination in order to get the Diploma of Higher Study.

Administrative general section: This section is for students and civil servants who hold the full baccalaureat. The age 1 imits to take the entrance examination are 18 to 25 . The length of the course of study is four years, including one year of practice and field work. Students who pass the final examination receive a diploma equivalent to the licence and are appointed to the rank of Administrator. The three-year academic curriculum includes a great number of business subjects such as Vietnamese economics and finance, administrative accounting, human relations, correspondence and office management, tax regulations, economics, finance, commercial law, organization and methods, commercial accounting, management, and international economy.

Chief clerk section: The entrance requirements are a Baccalaureat or Junior Diploma plus a Capacity Diploma of Administration or Law. The candidate must be between 20 and 34 years of age. The length of the program is one year: eight months of study at the Institute and four months of practice at central and regional offices. The program of study includes administrative problems, public office management, personnel management, and human relations, economics, finance, economy of Viet-Nam, economic problems, Vietnamese tax laws, problems related to budget and treasury, public correspondence, and administration accounting.

Students who pass the graduation examination are assigned to the Chief Clerk cadre. 
- Administrative capacity section: This evening course section, which leads to a Certificate of Administrative Capacity, aims to help civil servants and private workers improve their skills and prepare for entrance examinations for admission to administrative cadres. It includes two divisions: the General Administrative Division and the Economics and Finance Division.

The National Institute of Administration may be considered as a state higher school of business which offers training for government professions such as administrators and supervisors in all areas. ${ }^{1}$

For 15 years it has provided about 1,000 graduates qual ified for civil services jobs and supervisory positions. Now this Institute can train only about 250 a year--100 from its administrative generalist course, 50 from its graduate program, and 100 from its chief clerk course. $^{2}$ Each year the Administrative General Section accepts only 100 new students from the 1,600 applicants who would like to devote their careers to the civil service, but cannot be accommodated by the Institute. 3

Faculties of Law of the Universities. The Faculties of Law of the Universities include a number of business courses in the curriculum of the Licence in Law and the Doctorate in Economics.

${ }^{1}$ The National Institute of Administration, Catalogue (Saigon: National Institute of Administration, 1967), 93 pages.

${ }^{2}$ Viet-Nam Embassy, "Training the Supervisors," Viet-Nam Bulletin, Viet-Nam Information Series No. 7 (Washington, D. C.: Embassy of VietNam, 1969), p. 1.

3 Ibid., P. 3. 
The following courses appear in the program of the Licence in Law: political economy, economic terminology, financial legislation, commercial law, economy of Viet-Nam, budget technology, insurance laws, labor laws, and banking operations.

The doctorate level consists of three sections leading to the Diploma of Graduate Studies in Private Law, Diploma of Graduate Studies in Public Law, or Diploma of Graduate. Studies in Political Economy. Each diploma comprises two degrees corresponding to two years of study. The subjects taught in the section leading to the Diploma of Graduate Studies in the Political Economy are:

1. First degree: detailed political economy, mathematical economics, national accounting, history of economic doctrine, rural economy, demography.

2. Second degree: economic theory, statistics, economic and financial problems, money and banking, industry and political economy, economic geography.

The Graduates of the Faculty of Law can become lawyers, magistrates, administrators, or economists. 1

\section{Business Skill Championship Competition. Every year in Saigon}

there is championship competition in the areas of shorthand, typewriting, accounting, and IBM card punch in three languages (Vietnamese, French, and English) sponsored by "The Shorthand, Typewriting, and Accounting Association of Viet-Nam." Prizes are awarded at an important

'University of Saigon, op. cit., pp. 65-78. 
ceremony following the contests. This competition helps to improve the standard of business skills in Viet-Nam. 1

Summary on Business Education. There is no program of business education at the secondary level for students, age 12 to 18 . As a result, the Faculties of Pedagogy of Universities do not train business education teachers. The National School of Commerce is a professional business school for adults from 18 to 25 years of age and provides a maximum of 60 graduates a year.

At the University level there is only one Faculty, the Faculty of Political and Business Administration of the University of Da-Lat, a private institution, which offers business courses leading to the Licence's degree. The Administrative General Section and the Administrative Capacity Section of the National Institute of Administration and the undergraduate section of the Faculties of Law include in their curricula a number of bus iness courses.

At the graduate level, almost all subjects in the graduate section of Economics and Finance of the National Institute of Administration and in the Doctorate Diploma Section in Political Economy are business or business-related subjects (Table XI).

In short, so far there is no program of business education for the secondary school population, age 12 to 18 , and no formal business education faculty or department at any state university. This is a result of the fact that business education has not been considered an important component of the educational program in Viet-Nam.

${ }^{1}$ Ohio University Contract USAID (Education Report, AprilOctober 1966), unpublished, p. 29. 
TABLE XI

GENERAL OUTLINE OF THE PRESENT BUSINESS EDUCATION SYSTEM

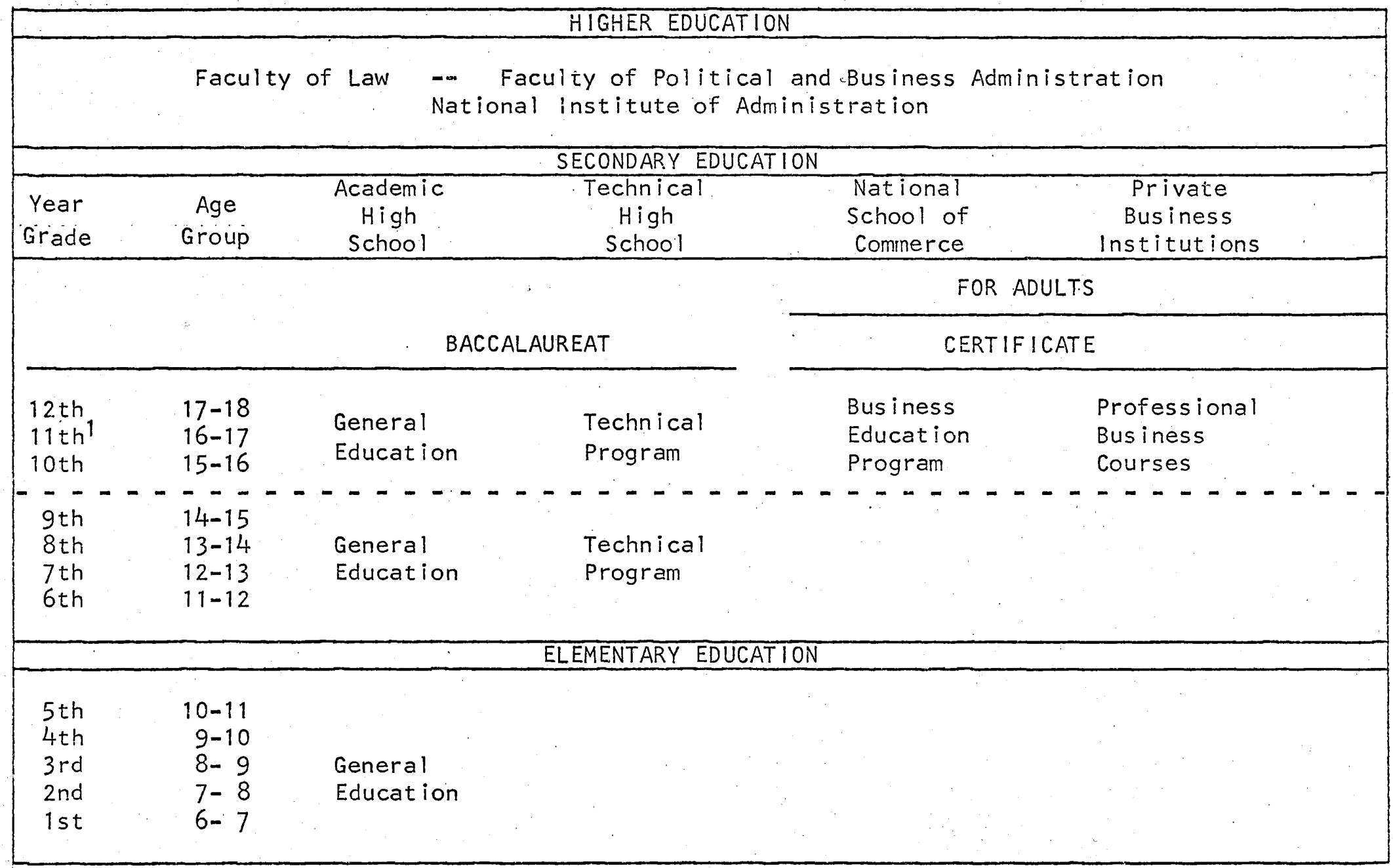

1 Two hours of economics per week. 
Statistical Analysis

Vietnamese educators have made a great effort to participate in the work of national rehabilitation. Numerous reforms have been effected to adapt Vietnamese schools to the principles of democracy and the needs of the nation. Qualitative development has always kept pace with quantitative development.

In 1955-56, the total elementary school enrollment was 602,000 or 31.35 percent of the school-age population (6 to 11 years). This figure increased to $2,014,000$ or 77.20 percent in 1968-69 (Table X11).

In secondary education, there were 531,013 students or 21.02 percent of the $12-18$ years population in 1968-69 compared to 53,500 or 3.07 percent in 1955-56 (Table X111).

In technical vocational secondary education there were 25,523 students in 1968-69 or 4.73 percent of the enrollment of the academic secondary pupils, as compared with. 3,723 or 2.66 percent in 1958-59 (Table $\times 111)$.

In higher education, there were 35,278 or 202 students per 100,000 inhabitants as compared with 7,327 students or 67 per 100,000 in 1958-59 (Table XIV). In 1965 the percentage of students in humanities, education and fine arts was 36 percent; in law and social sciences, 27 percent; in natural sciences, 20 percent; and in engineering, agriculture and medical sciences, 18 percent (Table XV).

In reality there has been an increase in enrollment every year at all levels. It is quite hopeful that the enrollment in elementary education will have reached 79.10 percent of the $6-11$ year old population in 1969-70. 
However if one class is followed through the 12 years of elementary and secondary school, the picture which is portrayed is peculiar to a highly selective academic educational system.

Back in 1956-57, 294,088 pupils (Table XVI) were enrolled in the first grade. In 1961-62, five years later, 140,558 or 47.77 percent of these pupils reached the terminal elementary year. In the same year only 73,181 were able to find a place in the sixth grade or first year of high school.

Seven years later, in the summer of 1969 , only 10,804 or 3.67 percent of the enrollment in the first grade in 1956-57 and 14.76 percent of the enroliment in the sixth grade in 1962-63 successfully passed the Baccalaureat 11 .

There was a dropout rate of 96.33 percent through the 12 years of elementary and secondary school or 85.24 percent during seven-year secondary school.

The statistical analysis of the achievement of the educational system shows the following results in school enrollment:

Elementary education: 79.10 percent population, age 6-11, in 1970 . Secondary education: 23.18 percent population, age 12-18, in 1970 . Vocational education: 4.73 percent of secondary academic students. Higher education: 202 per 100,000 inhabitants in 1969.

Dropout rate: 85.24 percent in secondary education during the last seven years. 


\section{TABLE XII}

QUANT ITATIVE DEVELOPMENT OF ELEMENTARY EDUCATION

\begin{tabular}{|c|c|c|c|c|c|}
\hline \multirow{2}{*}{$\begin{array}{l}\text { School } \\
\text { Year }\end{array}$} & \multirow{2}{*}{ Population 1} & \multirow{2}{*}{ Age $6-11^{3}$} & \multicolumn{3}{|c|}{ Enrol Iment } \\
\hline & & & Total $^{2}$ & Percentage & 1st Year ${ }^{2}$ \\
\hline $1955-56$ & $12,000,000$ & $1,920,000$ & 602,000 & 31.35 & \\
\hline $1956-57$ & $12,300,000$ & $1,968,000$ & 664,000 & 33.73 & 245,088 \\
\hline $1957-58$ & $12,600,000$ & $2,016,000$ & 864,000 & 41.96 & 294,293 \\
\hline $1958-59$ & $12,934,000$ & $2,069,000$ & $1,071,000$ & 51.76 & 381,489 \\
\hline $1959-60$ & $13,789,000$ & $2,205,000$ & $1,223,000$ & 55.46 & 423,891 \\
\hline $1960-61$ & $14,100,000$ & $2,240,000$ & $1,278,000$ & 57.05 & 427,730 \\
\hline $1961-62$ & $14,494,000$ & $2,296,000$ & $1.357,000$ & 59.10 & 453,499 \\
\hline $1962-63$ & $14,924,000$ & $2,353,000$ & $1,451,000$ & 61.66 & 480,645 \\
\hline $1963-64$ & $15,317,000$ & $2,412,000$ & $1,572,000$ & 65.17 & 522,065 \\
\hline $1964-65$ & $15,715,000$ & $2,473,000$ & $1,591,000$ & 64.33 & $508 ; 143$ \\
\hline $1965-66$ & $16,124,000$ & $2,484,000$ & $1,623,000$ & 65.33 & \\
\hline $1966-67$ & $16,543,000$ & $2,497,000$ & $1,754,000$ & 70.75 & \\
\hline $1967-68$ & $16,973,000$ & $2,552,000$ & $1,969,000$ & 77.15 & \\
\hline $1968-69$ & $17,414,000$ & $2,608,000$ & $2,014,000$ & 77.22 & \\
\hline $1969-70$ & $17,850,000$. & $2,856,000$ & $2,226,000$ & 79.10 & \\
\hline
\end{tabular}

${ }^{1}$ United Nations, Monthly Bul let in of Statistics, (January 1970), pp. 1-5.

2 Viet-Nam Department of Education, Educational Statistics, 1955-1969.

3 Multiplying the total population by 0.16 gives an estimate of the population, age 6-11. The 0.16 figure is based on two other figures, one for the population, age 6-11, of India (15.1 percent) and the other for Korea (16.0 percent). Viet-Nam Department of Education, Education Viet-Nam: Proposals for Reorganization (Saigon: Viet-Nam Department of Education, 1967), P. 264. 
TABLE XIII

QUANTITATIVE DEVELOPMENT OF SECONDARY EDUCATION

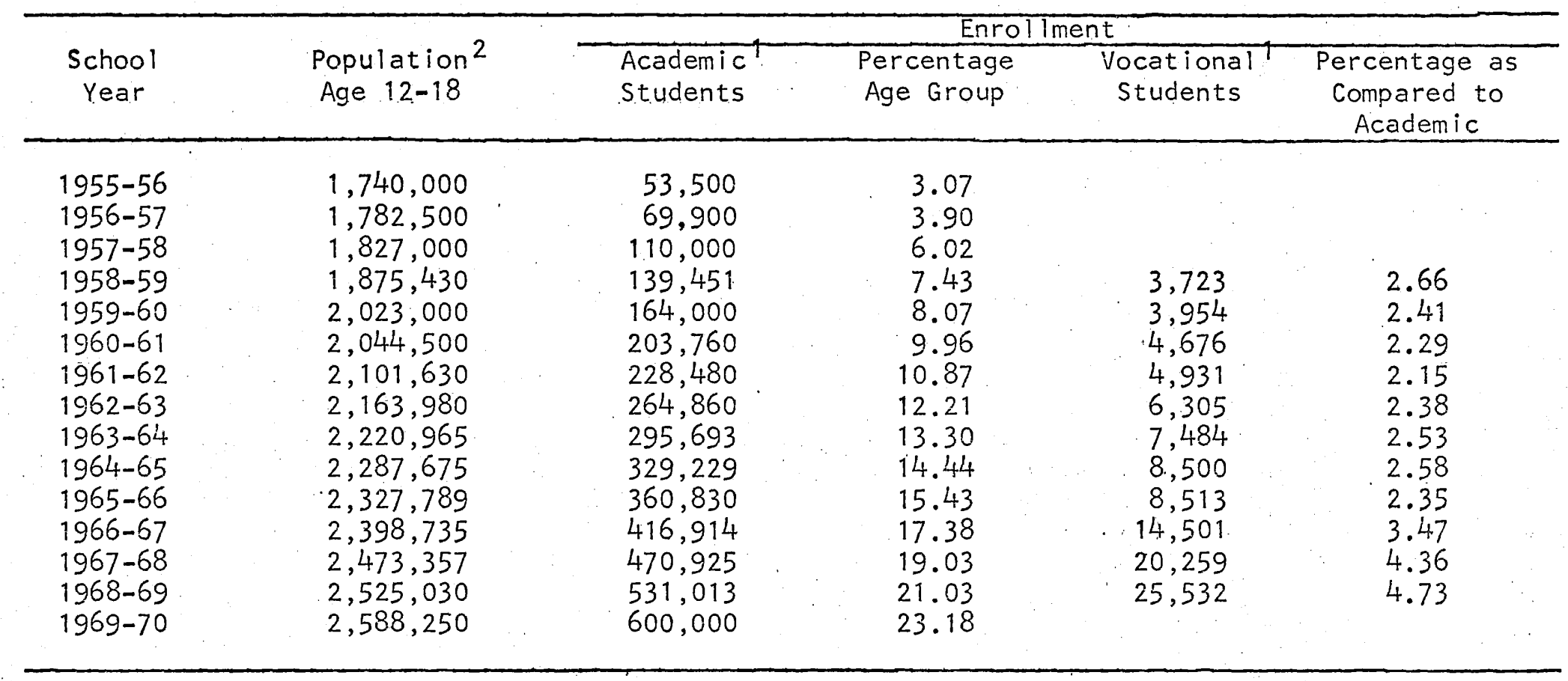

1Viet-Nam Department of Education, Educational Statistics, 1955-1969.

2 Multiplying the total population by 0.145 gives an estimation of population, ages 12-18. The 0.145 figure is based on the population, ages $12-18$, for India ( 14.5 percent) and Korea (14.8 percent). Education Viet-Nam: Proposals for Reorganization (Saigon: Viet-Nam Department of National Education, 1967), p. 265. 
TABLE XIV

QUANTITATIVE DEVELOPMENT OF HIGHER EDUCATION

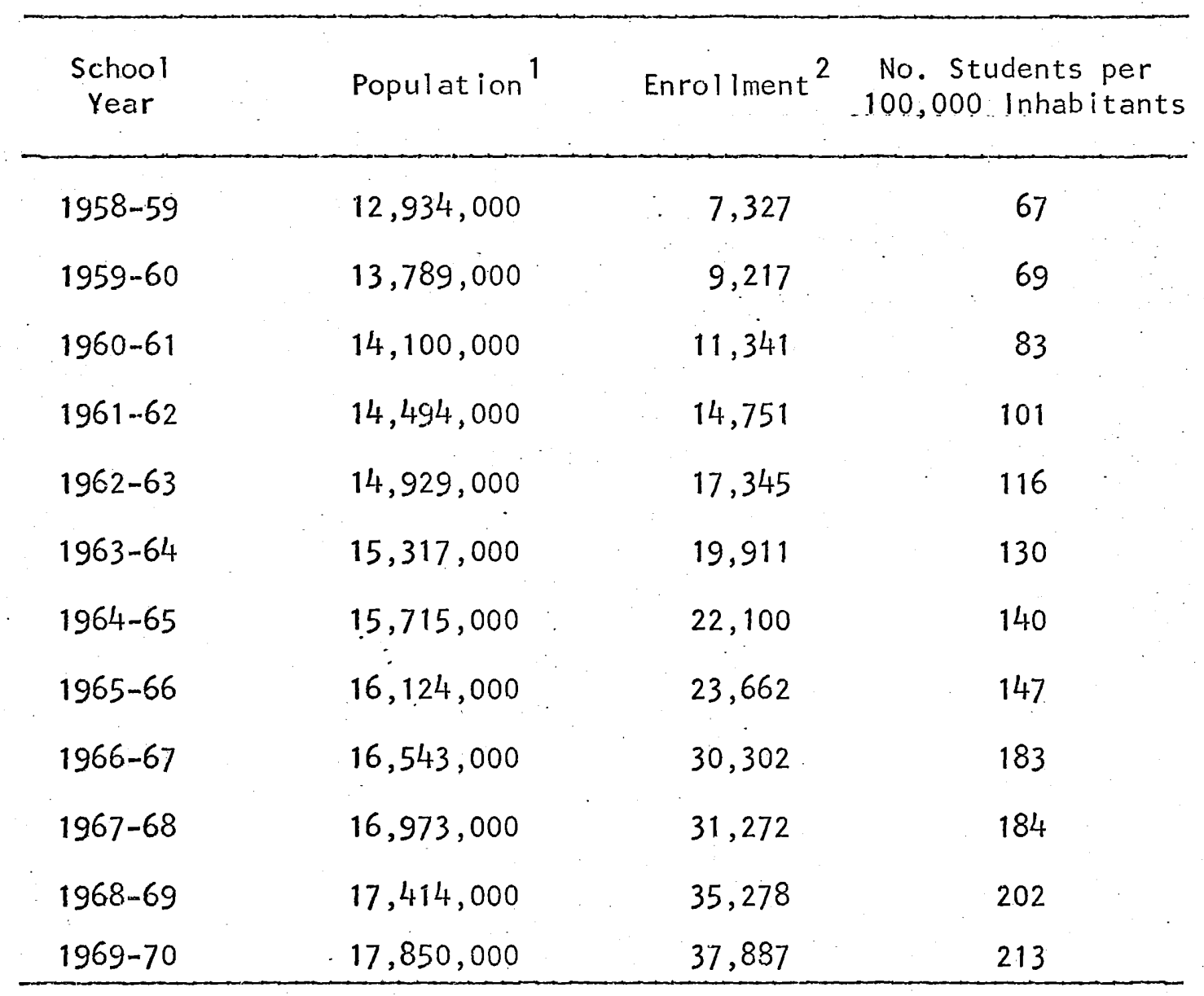

1United Nations, op. cit., pp. 1-5.

${ }^{2}$ Viet-Nam Department of Education, op. cit. 
TABLE XV

DISTRIBUTION OF STUDENTS BY FIELDS OF STUDY a

\begin{tabular}{cccccccc}
\hline Year & $\begin{array}{c}\text { Liberal } \\
\text { Arts }\end{array}$ & Law & Education $\begin{array}{c}\text { Fine } \\
\text { Arts }\end{array}$ & $\begin{array}{c}\text { Social } \\
\text { Sciences }\end{array}$ & $\begin{array}{c}\text { Engi- Medical } \\
\text { neering Sciences }\end{array}$ \\
\hline 1960 & 2869 & 2359 & 975 & 106 & 54 & 225 & 1906 \\
1964 & 6630 & 4702 & 1241 & 1220 & 1641 & 320 & 4350 \\
1965 & 8221 & 6336 & 998 & 437 & 865 & 345 & 4207 \\
\hline
\end{tabular}

PERCENTAGE DISTRIBUTION OF STUDENTS

\begin{tabular}{ccccc}
\hline Year & $\begin{array}{c}\text { Humanities, } \\
\text { Education, } \\
\text { Fine Arts }\end{array}$ & $\begin{array}{c}\text { Law, } \\
\text { Social } \\
\text { Sciences }\end{array}$ & $\begin{array}{c}\text { Natural } \\
\text { Sciences }\end{array}$ & $\begin{array}{c}\text { Engineering, } \\
\text { Agriculture, } \\
\text { Medical Sciences }\end{array}$ \\
\hline 1960 & 34 & 21 & 27 & 19 \\
1965 & 36 & 27 & 20 & 18 \\
\hline
\end{tabular}

a. Unesco Statistical Yearbook, 1966, pp. 192-193.

b. Ibid., p. 213 . 


\section{TABLE XV I}

DROP-OUT RATE DURING PAST TWELVE YEARS

\begin{tabular}{|c|c|c|c|c|c|c|}
\hline \multirow[t]{3}{*}{ School Year } & \multirow[t]{3}{*}{ Grade } & \multirow{3}{*}{$\begin{array}{l}\text { Number } \\
\text { of } 1 \\
\text { Students }\end{array}$} & \multirow{2}{*}{\multicolumn{2}{|c|}{$\begin{array}{c}\begin{array}{c}\text { Elementary and } \\
\text { Secondary } \\
\text { Schools }\end{array} \\
\text { Percentage }\end{array}$}} & \multicolumn{2}{|c|}{$\begin{array}{c}\text { Secondary } \\
\text { Schools }\end{array}$} \\
\hline & & & & & Perc & age \\
\hline & & & Success & Dropouts & Success & Dropouts \\
\hline Passed Baccalaureat 11 & & 10,804 & 3.67 & 96.33 & 14.76 & 85.24 \\
\hline $1968-69$ & 12 & $-20,440$ & 6.94 & 93.06 & 27.93 & 72.07 \\
\hline \multicolumn{7}{|l|}{ Baccalaureat 1} \\
\hline $\begin{array}{l}1967-68 \\
1966-67 \\
1965-66 \\
1964-65 \\
1963-64 \\
1962-63\end{array}$ & $\begin{array}{r}11 \\
10 \\
9 \\
8 \\
7 \\
6\end{array}$ & $\begin{array}{l}41,060 \\
36,632 \\
51,352 \\
53,325 \\
60,323 \\
73,181\end{array}$ & $\begin{array}{l}13.95^{2} \\
12.34 \\
17.34 \\
18.01 \\
20.49 \\
24.86\end{array}$ & $\begin{array}{l}84.05 \\
87.66 \\
82.66 \\
81.99 \\
79.51 \\
75.14\end{array}$ & $\begin{array}{r}56.10^{2} \\
50.01 \\
70.17 \\
72.86 \\
82.42 \\
100.00\end{array}$ & $\begin{array}{l}43.90 \\
49.99 \\
29.83 \\
27.14 \\
17.58\end{array}$ \\
\hline \multicolumn{7}{|l|}{ Entrance Examination } \\
\hline $\begin{array}{l}1961-62 \\
1960-51 \\
1959-60 \\
1958-59 \\
1957-58\end{array}$ & $\begin{array}{l}5 \\
4 \\
3 \\
2 \\
1\end{array}$ & $\begin{array}{l}140,558 \\
156,277 \\
231,151 \\
275,639 \\
294,293\end{array}$ & $\begin{array}{r}47.77 \\
53.10 \\
78.54 \\
93.66 \\
100.00\end{array}$ & $\begin{array}{r}52.23 \\
46.90 \\
21.46 \\
6.34\end{array}$ & & \\
\hline
\end{tabular}

${ }^{1}$ Viet-Nam Department of Education, Educational Statistics, 1958-69.

${ }^{2} \mathrm{~A}$ number of students repeat this year. 


\section{ENV IRONMENT}

Characteristics of the Vietnamese Business system

For almost a century colonial rule resulted in exclusion of Vietnamese from effectively running their country. The people's sense of organization, leadership, and responsibility was blunted. Economically, capitalistic development was arrested and enterprise-m

a fundamental factor in the economic development of a nation--was lost little by little. Under the colonial regime only farming along traditional $l$ ines was reserved for the Vietnamese while industry, commerce, transport, banking, modern farming-mall important areas of business--excluded the local people. Two careers were open to them: peasants or subsistence farmers and functionaries or mandarins of low echelon.

The guiding principles of the colonial economic system in Viet-Nam were:

1. the exploitation of natural resources for exports; and

2. the reservation of the local markets for manufactured imported products.

Every natural resource that could be profitably exploited was exploited, and only the industries which supported those exploitations were allowed to exist. This resulted in the absence of local production to satisfy the local demand for manufactured goods.

Commerce is the second most important form of economic activity in Viet-Nam (Table XVII). The contribution of commerce to the 
TABLE XVII

GROSS DOMESTIC PRODUCT BY SECTOR OF ORIGIN, 1955a

(Billions of Piasters)

\begin{tabular}{|c|c|c|c|}
\hline Sector & Amount & Percent & \\
\hline Commerce & 17.1 & 24 & \\
\hline Agriculture and 1 ivestock & 17.0 & 24 & \\
\hline Government & 9.5 & 13 & \\
\hline Rental income & 5.7 & 8 & ; \\
\hline Transportation & 4.3 & 6 & \\
\hline Fishing & 4.2 & 6 & \\
\hline clothing and textiles & 2.6 & 3 & \\
\hline Food processing & 1.3 & 2 & \\
\hline Domestic services & 1.3 & 2 & \\
\hline Tobacco & 1.1 & 1 & \\
\hline other & 7.9 & 11 & \\
\hline . TOTAL & 72.0 & 100 & \\
\hline
\end{tabular}

a. National Bank of Viet-Nam, Estimations of National Income of Viet-Nam in 1955 (Saigon: National Bank, 1956), P. 14. 
national income was 20 percent (as compared with 10 percent for agriculture and fisheries combined)! Commercial activity, mainly in imports and exports, expanded greatly under the colonial regime and is still growing today. Special groups established dominant positions in the commercial sector and have been able to exploit them to some degree. During the war, inflationary pressures have offered favorable opportunities for commercial profits, and the entrenched groups have taken advantage of them.

Commercial activity is carried on at four principal levels. At the top are large international trading companies, next are the domestic and distributing businesses, then come the small retail stores of the cities and towns, and finally the full or part-time merchants and peddlers in the market place of the cities, towns, and villages.

Before the nationality regulations of 1956 which offer Vietnamese nationality to Chinese born in Viet-Nam, there were 800,000 Chinese who controlled well over 80 percent of the retail trade. ${ }^{2}$ There were 3,475 manufacturing and 13,813 non-manufacturing Chinese firms in Viet-Nam. A considerable amount of Chinese capital has been invested in hotels, restaurants, and theatres. For decades, large Chinese rice merchants have, themselves, transported rice from the interior to Saigon and have exploited the rice market.

1 United Nations, Toward the Economic Development of the Republic of Viet-Nam (New York: United Nations, 1959), pp. 24-26.

${ }^{2}$ Tsung To Way, "A Survey of Chinese Occupations," printed in Richard W. Lindholm, Viet-Nam The First Five Years (Michigan: Michigan State University Press, 1959), Pp. 118-125. Tsung To Way was the Manager of the Bank of China in Saigon. 
How do the estimated 800,000 Chinese in Viet-Nam earn a living? Unlike French businessmen who make large investments in farming, mining, forestry, plantations, fisheries, industrial and commercial enterprises, the economic activities of the chinese are mainly in the field of commerce and trade. 1

During the last decade while almost all active Vietnamese have been involved with the war, Chinese commerce and trade in Viet-Nam has expanded more than ever before.

In addition to the Chinese business, many modern farming plantations and large-scale industrial organizations are owned by French investors. ${ }^{2}$ The famous high quality Viet-Nam rubber which is the country's principal export product and main source of foreign exchange comes almost entirely from the large plantations established by French companies, which are well organized with planting systems, tapping methods, and processing plants. ${ }^{3}$ The exploited area before the war, in 1959, was 53,870 hectares, of which only 8,000 were owned by Vietnamese. Viet-Nam today is on the way to industrialization and the index of industrial production häs been increasing despite the war (Table $X V \mid 11)$.

The most important weaknesses in the business system are the preponderant role of foreigners, the prevalence of monopolistic powers in certain sectors, and the massive consumer good imports (Table $X \mid X)$.

1 lbid., p. 118.

ZUnited Nations, op. cit., p. 157.

3United Nations, op. cit., pp. 52-55. 
TABLE XV $\|$

INDEX NUMBERS OF INDUSTRIAL PRODUCTIONa

\begin{tabular}{lllllll}
\hline & 1962 & 1963 & 1964 & 1965 & 1966 & 1967 \\
\hline General & 85 & 100 & 113 & 135 & 146 & 162 \\
Mining & 68 & 100 & 69 & & & \\
Manufacturing & 86 & 100 & 115 & 138 & 149 & 166 \\
Food, Beverages, Tobacco & 88 & 100 & 116 & 141 & 151 & 175 \\
Textiles & 73 & 100 & 105 & 119 & 124 & 114 \\
Electricity and Gas & 89 & 100 & 115 & 150 & 155 & 176 \\
\hline
\end{tabular}

a. United Nations, Statistical Yearbook 1968, p. 161. 
TABLE XIX

EXTERNAL TRADEa

(In Millions of U.S. Dollars)

\begin{tabular}{ccc}
\hline Year & Import CIF & Export FOB \\
\hline 1959 & 225 & 75 \\
1960 & 240 & 86 \\
1961 & 255 & 71 \\
1962 & 265 & 57 \\
1963 & 286 & 77 \\
1964 & 298 & 49 \\
1965 & 357 & 36 \\
1966 & 444 & 24 \\
1967 & 538 & 16 \\
\hline
\end{tabular}

a. United Nations, Statistical Yearbook 1968, pp. 762-763. 
Since gaining independence, the major objective of Viet-Nam has been the Vietnamization of the economy. This requires businessmen who are technically capable of effective operation to assume new commercial and industrial responsibilities. They must be academically trained and experienced.

\section{Present Business Situation}

A survey made by the Ministry of Labor in 1966 resulted in an estimated total labor force of 6,105,000 which included 3,965,000 in the agricultural sector and 2,140,000 in other sectors. 1 (Table XX) of this labor force 134,000 were in commerce, banking and insurance; 168,000 in manufacturing; 149,000 in transportation and communication; 330,000 in government employment; and 67,000 in other services. In 1967 the U.S. sector employed 127,418 Vietnamese employees in which there were 45 executive and managerial workers; 8,224 professionals and technicians; 15,917 clerical workers including 4,056 secretaries, stenos and typists; 2,914 recordkeeping clerks; 504 office equipment operators; and 949 sales workers. ${ }^{2}$

The National Institute of Statistics reported that in 1960 there were 7,328 manufacturing companies and in 1966, 1,783 of them submitted returns to the Ministry of Economy. ${ }^{3}$ Almost the entire manufacturing capacity of the country is concentrated in the area of Saigon and BienHoa. An account of the seven principal groups of industry is shown in

${ }^{1}$ Thuc, 으. cit., pp. 123-148.

${ }^{2}$ Thuc, op. cit., p. 135.

${ }^{3}$ Thuc, op. cit., pp. 261-346. 
TABLE XX

DISTRIBUTION OF LABOR FORCE BY SECTOR, 1966a

Total Population: $16,500,000$

Sector

Agriculture (general)

$3,965,000$

Plantations

26,000

Fishing

254,000

Mining and Quarrying

2,000

Manufacturing and Handicrafts

168,000

Construction

131,000

Commerce, Banks, and Insurance

134,000

Transportation and Communications

149,000

Electricity, Gas, Water, and Sanitary Services

4,000

Government Employees

Public Administration

330,000

Armed Forces

680,000

Other Services

67,000

Domestic Servants

115,000

U. S. Sector (Excluding Construction)

80,000

TOTAL LABOR FORCE

$6,105,000$

a. Thuc, op. cit., p. 127. 
Table $\times x 1^{1}$

In 1967, the most important industries according to the capital invested were the following: ${ }^{2}$

$\begin{array}{lc}\text { Cotton weaving and spinning } & \text { VN } \$ 4,200 \text { million } \\ \text { Beverages } & 3,500 \\ \text { Paper } & 2,400 \\ \text { Tobacco } & 2,100 \\ \text { Cement and products } & 2,000 \\ \text { Pharmaceuticals } & 1,500\end{array}$

All of the above branches of industry have modern plants and machinery and require modern management techniques.

Prospects of Post-War Business

When the war ends Viet-Nam will face practically every economic problem that an underdeveloped country in the twentieth century could face.

A plan for post-war development was compiled by a team of economists. It sets forth a step-by-step strategy for making Viet-Nam economically self-supporting during the decade following a cease-fire. The goals of the plan are:

1. To increase the gross national product at a rate of four percent per annum in the reconstruction period and at five percent per annum in the period of development, or by 52 percent over the entire decade following the war.

${ }^{1}$ Thuc, op. cit., p. 263.

2 Thuc, op. cit., p. 265. 
TABLE XXI

THE STRUCTURE OF VIETNAMESE INDUSTRY, 1967a

(Millions of Vietnamese Piasters;

VN $\$ 118=$ U.S. $\$ 1.00)$

\begin{tabular}{|c|c|c|c|c|c|c|}
\hline Group & $\begin{array}{l}\text { Type of } \\
\text { Industry }\end{array}$ & $\begin{array}{l}\text { Capital } \\
\text { Invested }\end{array}$ & $\begin{array}{l}\text { Value of } \\
\text { Machinery }\end{array}$ & $\begin{array}{c}\text { Work Force } \\
\text { (persons) }\end{array}$ & Sales & Remarks \\
\hline 1 & $\begin{array}{l}\text { Food, } \\
\text { Beverages, } \\
\text { Tobacco }\end{array}$ & 8,159 & 3,585 & 17,300 & 34,575 & $\begin{array}{l}\text { Excluding } \\
\text { Binh-Duong } \\
\text { Quang-Ngai } \\
\text { and small- } \\
\text { scale sugar } \\
\text { mills. }\end{array}$ \\
\hline 2 & Textiles & 5,768 & 1,859 & 18,000 & 4,660 & \\
\hline 3 & $\begin{array}{l}\text { Paper, } \\
\text { Leather, } \\
\text { Rubber }\end{array}$ & 2,758 & 1,233 & 3,650 & 1,506 & $\begin{array}{l}\text { Excluding } \\
\text { sawmills }\end{array}$ \\
\hline 4 & $\begin{array}{l}\text { Basic and } \\
\text { Processed } \\
\text { Chemicals }\end{array}$ & 2,653 & 1,024 & 9,310 & 5,064 & $\begin{array}{l}\text { Excluding } \\
\text { An-Hoa-Nong.- } \\
\text { Son Complex }\end{array}$ \\
\hline 5 & $\begin{array}{l}\text { Glass, } \\
\text { Ceramics, } \\
\text { Cement }\end{array}$ & 2,562 & 1,449 & 3,960 & 1,405 & $\begin{array}{l}\text { Excluding } \\
\text { Handicrafts }\end{array}$ \\
\hline 6 & $\begin{array}{l}\text { Mechanical } \\
\text { and Metal } \\
\text { Products }\end{array}$ & 1,508 & 363 & 5,050 & 5,065 & . \\
\hline 7 & Electrical & 520 & 159 & 3,320 & 990 & $\begin{array}{l}\text { Excluding } \\
\text { electrical } \\
\text { generation }\end{array}$ \\
\hline & TOTALS & 23,928 & 9,771 & 60,590 & 53,265 & \\
\hline
\end{tabular}

a. Thuc, op. cit., p. 263. 
2. To increase per capita income by about 20 percent over the entire period.

3. To increase agricultural output by at least 50 percent.

4. To double industrial output within the first ten years of peace.

5. To engineer an overall economic growth rate of five to seven percent a year. 1

To accomplish this plan an estimated U. S. $\$ 2,500$ millions $^{2}$ invested over a ten-year period will go to public works, agriculture, forestry, and small industries. Top managers, supervisors, technicians, and workers must be provided for in the elaboration of this plan.

In the immediate post-war years, the tasks of industrial reconstruction and repair are readily identified and rated top priority. It is estimated that about 300,000 jobs will have to be created each year. ${ }^{3}$ In fact, if a basic investment program such as this is implemented, there is likely to be a shortage rather than an abundance of skills, and large training programs will have to be undertaken.

A population of $22,500,000$ is projected for 1978, with $3,360,000$ children in the primary school age group, $4,100,000$ of secondary age, and over 2,000,000 of university age... Primary school enrollments are thought likely to increase to $3,159,000$ (78 percent of the age group). Secondary school enrollment should increase from a present 471,000 (with only 15,000 or three percent of the pupils in technical secondary schools) to $1,355,000$ with a far higher proportion, about 30 percent, in the technical schools; and university enrollments are expected to

1 1bid., Volume 111 , pp. 1-76.

2 Ibid., Volume 111, p. 10

3 ibid., p. 19. 
increase from 32,600 to 95,000 , maintaining their present seven percent proportion of secondary enrollments. 1

Strong emphasis has been placed on the need for educational planning and programs to improve the productive capability of the labor force. The post-war development report also stresses the increase in percentage of the secondary vocational education population from three percent to 30 percent in one decade.

On the economic and industrial side, Viet-Nam has faced the task of converting a colonial business system into a national business system and in the near future will face the problem of converting a wartime economy into a peacetime economy. This requires good managers, supervisors, and technicians which technical vocational education should provide. Business education today could offer well-trained white collar workers, as well as managers and supervisors at all levels who are needed for an efficient national business system and for post-war economic reconstruction.

\section{Transfer of Technology and Educational Investment}

A transfer of technology from advanced industrialized countries to Viet-Nam is necessary for its development. Technology involves changes in artifacts, labor and managerial skills. The training of needed technicians is an important part of the process being transferred.

Not only does Viet-Nam lack bureaus of industrial statistics and technical studies that are well equipped, but also managers, technicians, and supervisory personnel.2

IIbid., Volume 11, p. 406.

${ }^{2}$ Sa, Nguyen-Phuc, A General Report on Industrial Development, printed in Richard $W$. Lindholm, editor, Viet-Nam, The First Five Years (Michigan: Michigan State University Press, 1959), p. 241. 
Educational investment which is an important part of the development process includes two different forms, each of which is necessary

to the other.

On the one hand, there is the vocational and professional oriented training geared to specific needs, in which the pay-off seems surer and quicker. On the other hand, there is the education pointing towards longer-run institutional changes--with the social matrix setting and conditioning the value of technology--in which the return is much less certain and the pay-off often doubles. 1

The latter category includes more general educational programs which encourage basic literacy and basic tools that are relevant to changing conditions.

The real trouble in developing countries is not merely a shortage of specific skil.ls, but a more general and pervasive lack of skills and abilities to digest, absorb, and diffuse the modern technology. ${ }^{2}$

Economists in the past have tended to concentrate too much on the inability of developing countries to accumulate capital but recently they have come to consider human resources as an important factor for economic development. In any economy it is ultimately the entrepreneural or managerial class which is the initiator and coordinator of economic activity. For Viet-Nam the expansion and development of such a class is a crucial point in its development programs. Unfortunately, as the scope of economic development has increased, especially during more than two decades of war, it has become painfully obvious

$1^{1}$ New W. Chamberlain, "Training and Human Capital," printed in Daniel L. Spencer and Alexander Woroniak, The Transfer of Technology to Developing Countries (New York: Frederick A. Praeger, Publishers, 1967), p. 156.

2Hla Myint, The "Widening Gap" of the Underdeveloped Countries: A Critical View (New Haven: Yale University Economic Growth Center, 1965), P. 12 . 
that Viet-Nam is suffering an acute shortage of people with the requisite training for business management. This shortage has been reflected by the presence of expatriate personnel in the field of industry and commerce, which leads to social friction. Entrepreneural ability is not enough by itself; skilled manpower must also be available. Factories need to be managed, machines need to be operated, banks have to be staffed. There is a need for trained and skilled workers in all sectors of economic activity. Furthermore operative skills are of equal importance. While in advanced countries many institutions provide a continuous flow of skills which their industrialized economies need, in Viet-Nam the educational system, especially the higher secondary education, is geared for the most part to creating graduates equipped with culture rather than with technical knowledges. Since the recovery of independence, despite efforts of the whole people to cope with the world movement toward industrialization and technical development, the long, undesirable war has slowed down all progress. The minority of Vietnamese youths who have been offered an academic education that is rigid in its methods are deprived of an adequate practical education which would enable them to contribute to the management of their country in all aspects of national life, especially in economic development.

If Viet-Nam is to achieve success in its economic development it must discover, cultivate, and develop an indigenous business worker and managerial class and do so as quickly as possible. This clan must comprise not only private businessmen but also civil servants responsible for directing the economic activities of government departments and 
enterprises. A business education system will aim at providing qual ified members for the group. The shortage of potential business workers and managers is due to the lack of a business education system which prepares practical intellectuals, engineers of developing economic environment.

Education in a developing country has a special function. It cannot be concerned merely with the development of culture. It must attempt to provide the pupil with means of adapting himself to the realities of modern life and to provide him with the intellectual tools for building for a better future. 1

An educational investment in the business education field is necessary for the transfer of technology from advanced countries to Viet-Nam. Because the progress of industrialization is a means to achieve economic independence and to assure the survival of the country, there is an urgent need to implement in the educational system in VietNam a business education program which provides managers, technicians, and supervisors needed for industrialization.

Conclusion on the Analys is of the Vietnamese Educational Program and Its Environment

In 1965, a five-year plan was worked out by the Ministry of Education and adopted by the Government. Its main objectives were:

1. Increase the ratio of children of school age attending primary schools from 65 percent to $85^{\circ}$ percent in five years.

2. Provide more school buildings so that in five years' $t$ ime 40 percent, instead of 20 percent, of the children who complete their

${ }^{1}$ Thomas L. Norton, Public Education and Economic Trends (Massachusetts: Harvard University, Graduate School of Education, 1939), p. 172 . 
primary schooling can be admitted to public secondary school.

3. Reorganize the present secondary schools as comprehens ive schools teaching agriculture, technology, and commercial subjects.

4. Increase the number of universities from four to five and diversify higher education in accordance with the country's needs.

5. Reorganize technical and agricultural education so as to cover post-graduate studies and make more specialization possible. ${ }^{1}$

In the school year $1969-70$ the ratio of school-age pupils attending primary schools was 79.10 percent and 35 percent of the students who completed primary schooling entered public high schools.

In 1968, eleven high schools were reorganized as comprehensive high schools; however, only a few business subjects have been offered on an unofficial, voluntary, non-credit basis using untrained teachers.

The number of universities has been increased from four to five as planned, but because of the limited facilities and teaching staffs higher education has not been diversified enough to meet the country's needs. So far no Faculty or Department of Business Education exists in any state university.

The statistical analysis also reveals that (1) in the school year 1969-70 approximately 76 percent of the population ages 12 to 18 did not have an opportunity to attend high school and, as a result, the majority of youths are suffering from the lack of secondary education; and (2) the percentage of enrollment of vocational technical

${ }^{1}$ From the report presented at the XXIX Session of the International Conference on Public Education, Unesco, International Yearbook of Education, 1.966, pp. 398-399. 
students is very low compared to that of academic students $(4.73$ percent in 1969-70). This is quite unfavorable to the national econonic development. The percentage of vocational students is much higher in some other Asian countries (Table XXII).

Furthermore, the waste at the secondary stage of education is serious, as indicated by the large number of students ( 85 percent from 1962 to 1969) who fail to complete the seven-year secondary education. Important aspects also have been found in the analys is of the environment. Weaknesses exist in the business system such as the preponderant role of expatriates, the prevalence of monopolistic power in a number of economic sectors, and the massive consumer-goods imports. Viet-Nam is in great need of business managers and workers technically capable of effective operation to assume new commercial and industrial responsibilities.

The Postwar Development Policies and Programs estimated that the enrollment of vocational-technical students will increase to 30 percent of the enrollment of academic students in 1978, from 25,523 in 1968 to 452,000. These students should be trained to become blue collar and white collar workers for about 300,000 jobs which will be created every year after the war, under the economic development program.

The government will give priority to the technical and vocational school. Within two years we must enroll about 10,000 students, twice the present figure, in higher technical vocational education. 1

The present Vietnamese educational system is highly selective and academically oriented. As a result:

${ }^{1}$ President of the Republic, op. cit., p. 3. 
TABLE XXII

ENROLLMENT IN SECONDARY EDUCATION IN 1964

\begin{tabular}{lllllll}
\hline Country & Population & Age 12-18 & $\begin{array}{l}\text { Academic } \\
\text { Students }\end{array}$ & Percentage & $\begin{array}{c}\text { Vocational } \\
\text { Students }\end{array}$ & $\begin{array}{c}\text { Percentage } \\
\text { to Academic }\end{array}$ \\
\hline Japan & $96,906,000$ & $15,051,370$ & $8,970,354$ & 59.00 & $2,060,158$ & 22.97 \\
China & $12,070,000$ & $2,750,150$ & 483,871 & 17.60 & 106,843 & 22.08 \\
Korea & $27,633,000$ & $4,007,780$ & $1,003,871$ & 25.04 & 162,666 & 16.21 \\
Thailand & $29,700,000$ & $4,307,500$ & 311,644 & 7.24 & 38,228 & 12.27 \\
\hline
\end{tabular}

${ }^{1}$ Unesco, Statistical Yearbook, 1966.

2 International Yearbook of Education, 1965. 
The academic level of Vietnamese universities is high. Many university professors have studied at French and other Western institutions of higher learning, and in many cases have won academic distinction abroad. 1

Viet-Nam has a considerable stock of extremely highly educated citizens... . It is equipped with a range of high quality institutions. ${ }^{2}$

However, Viet-Nam is now facing the problem of mass and practical education to avoid waste of human resources, to develop technical vocational education, to answer the needs of the country today, to achieve economic independence, and in the future--the post-war period-for rehabilitation and development.

Technical vocational education includes technology and clerical and business skills. These two areas interrelate with each other in the movement toward economic development.

1 American University, Area Handbook for South Viet-Nam (Washington, D. C.: U. S. Government Printing Office, 1967), p. 156.

2Guy Hunter, Higher Education and Development in South-East Asia (Paris: Unesco, 1967), P. 159. 
CHAPTER IV

FINDINGS ON BUSINESS EDUCATION IN FOREIGN COUNTRIES AND ON

THE ANALYSIS OF THE VIETNAMESE EDUCATIONAL

SYSTEM AND ITS ENVIRONMENT

\section{PRINCIPLES OF BUSINESS EDUCATION}

Through the review of literature on business education in countries other than Viet-Nam a number of concepts of business education relative to philosophy and objectives and organization, methods, and curriculum were identified.

\section{Philosophy and objectives}

1. Business education is a component of a total educational program of a democratic society.

2. Business education contributes to the realization of mass and practical education in the community.

3. Business education helps people to become good citizens, helps individuals to adjust to their business environment and to encourage business enterprises and initiatives.

4. Business education supplies educators and educated skilled businessmen and workers in the business areas of the national economic development.

5. The objectives of business education are general education for every student, vocational for students who need employment upon completion of high school, prevocational for college-bound students, and professional for college and university students. 
6. Business education aims at developing intelligence.

7. Business education should reconcile culture and career.

8. Business education should be built on a general basic business education which will allow adaptation to changes.

9. Business education provides practical intellectuals such as administrators and managers, technicians and supervisors, and clerical workers.

10. A well-founded system of general education is always supplemented and complemented by various types of vocational education-one of which is business education.

\section{Organization, Methods and Curriculum}

1. At the secondary level business education is usually offered either in the specialized business school or in the comprehensive or multi-track high school.

2. Teaching business education in the comprehensive or multitrack high school is based mainly on the ideal of equal opportunities in a democratic society.

3. The comprehensive and multi-track high schools which provide instruction in several vocational fields and a diversified list of academic electives must have a large staff and suitable facilities, which is relatively costly.

4. Teaching business education in the specialized business schools is based mainly on economy and the availability of teachers.

5. There has been a tendency for the traditional academic high school to become comprehensive or multi-track in a number of countries. 
6. Private secondary business institutions usually prepare students for Certificates of business professional aptitude.

7. Private secondary business institutions are but a part of adult vocational education.

8. Business education should be conducted in a living and educational manner in order to develop thinking, observations, and initiatives.

9. Business education should be linked to reality to conform to the spirit of practical education.

10. Business education is usually offered to students above 14 years old who have completed the lower secondary education.

11. The program of business education should be built on a general basic business education which will be adaptable to changes.

12. General education is also offered parallel to business education in the specialized business school or in the business education stream of the multi-track high school.

13. Business teacher training is a program of the school of education or the school of business in the universities.

14. The developing countries usually send students abroad for business education training.

15. The curriculuin of business education should parallel the industrial and economic development of the nation. 


\section{THE VIETNAMESE. EDUCATIONAL SYSTEM}

The analysis of the Vietnamese educational system has revealed several characteristics relative to organization and principles, the business education system, and achievement of the educational system.

\section{Organization and Principles}

1. The policy of the Republic of Viet-Nam is to realize a system of mass and practical education.

2. The educational system has always adapted to changes of the modern world.

3. The educational system is humanistic, nationally centered and open to all cultural influence.

4. The educational system is highly selective and academically oriented.

5. The two-track system is being adopted--the academic track and the vocational track. The vocational school parallels the academic school.

6. Comprehensive education is developing in Viet-Nam. A third track of comprehensive high schools is being experimented with in a program of rèorganization of the educational system.

7. A single continual twelve-year school system has been adopted in order to promote the ideal of equal opportunity and democracy.

8. Technical vocational education is receiving high consideration by the government. 
The Business Education System

1. Business education at the secondary level is offered by the unique National School of Commerce and by private institutions.

2. The National School of Comnerce which is a business school for adults offers professional business courses in a common program for all students leading to a three-year certificate of commerce.

3. Graduates from the National School of Commerce usually seek employment as clerical workers or secretaries in government offices or in private enterprises.

4. Private business education institutions which exist in large cities, mostly in Saigon, offer short professional business courses for adults.

5. Business education is being taught in the Demonstration High Schools and in the Pilot Comprehensive High Schools on an unofficial, non-credit, and voluntary basis. Business courses in most cases are taught by untrained business teachers.

6. So far no official program of business education exists at the secondary level for students, age 12 to 18 .

7. No business education faculty exists in any state university.

8. The training of administrators, supervisors, and civil servants for the government offices is being conducted at the National Institute of Administration which graduates about 250 a year.

9. The Faculty of Political and Business Administration of the University of Da-Lat, a private institution, offers two specialized business education areas: Economics and Finance, and Industrial Management. The Faculty graduated 395 students in the last three years. 
10. The Faculties of Law of universities include business subjects such as Economics, Finance, and Banking in the curriculum.

11. Both the National Institute of Administration and the Faculty of Law of the university offer graduate studies in Economics and Finance leading to the Diploma of Higher Studies in Economics and Finance.

12. The Faculty of Law of the University of Saigon also offers the doctor's degree in economics.

13. The Shorthand, Typewriting, and Accounting Association of Viet-Nam organizes every year the Championship Competition in the area of Shorthand, Typewriting, and Accounting which helps to improve business skills.

Achievement of the Educational System

1. In the school year $1969-70,79.10$ percent of the population age six to 11 attended elementary school, and 35 percent of the pupils who completed elementary schooling entered public high schools.

2. In the school year 1969-70, approximately 76 percent of the population age 12 to 18 did not have the opportunity to attend high school and, as a result, the majority of youths suffer the lack of secondary education.

3. The percentage of vocational students is very low as compared to academic students (4.73 percent in 1969-70).

4. The dropout rate in the secondary stage of education is serious--85 percent of secondary students failed to complete the seven-year secondary education in the last seven years. 
5. In higher education there were, in 1969-70, 37,887 students or 213 students per 100,000 inhabitants, or about seven percent of the enrollment of high schools students.

6. The percentage of students enrolled in Law and Liberal Arts is high as compared to those in Sciences and Technical-Vocational Studies.

\section{ENVIRONMENT}

The following factors have been found through the analys is of the environment:

1. For almost a century under colonization the people's sense of organization, leadership and responsibility were blunted.

2. Capitalist development was arrested and enterprise was lost little by little.

3. Only the industries which supported the exploitation of the colonial regime were privileged to exist.

4. Important areas of business have been in the hands of expatriate people.

5. Business activities which, under the colonial regime, mainly were import and export are still being influenced by the same practice unt il today.

6. The important weaknesses of the present business system are the preponderant role of foreigners, the prevalence of monopolistic powers in certain economic sectors, and the massive consumption of imported goods. 
7. Viet-Nam is facing a double task--to convert a former colonial economic system into an independent economic system, and later a wartime economy into a peacet ime economy.

8. In 1966 Viet-Nam had a labor work force of 6,105,000; among them 3,965,000 were in the agricultural sector and 2,140,000 in others.

9. It is estimated that about 300,000 new jobs should be created every year in the decade after the cease-fire.

10. Viet-Nam is in great need of well-trained and experienced business managers, supervisors, and workers capable of assuming commercial and industrial responsibilities.

11. Viet-Nam needs technicians for the process of transfer of technology for industrialization.

12. Viet-Nam needs to develop a qualified managerial class which is the initiator and coordinator of national economic activities.

13. The Report of Postwar Economic Development stressed the need of educational planning and programs to improve the production capability of the labor force.

\section{SUMMARY OF FINDINGS}

The Vietnamese educational system is highly selective and academically oriented. Comprehensive education is developing and the educational program is changing to fit the needs of the nation. However, so far no official curriculum of business education exists in any State University or any public high school.

Viet-Nam today, which has inherited a colonial business and economic system, is faced with the task of converting it into an 
independent economic system. This requires well-trained business workers, supervisors, and managers in every economic sector. In addition there is a great need to provide a capable labor work force for rehabilitation after the war and for industrialization. 


\section{CHAPTER V}

\section{A PROPOSAL FOR DEVELOPMENT}

\section{PHILOSOPHY AND OBJECTIVES}

In Viet-Nam, the social ethic status divides the society into four classes: "Si, Nong, Cong, Thuong," that means Intellectuals, Farmers, Artisans, Businessmen. This idea, dated back some thousand years, still exists today. It reflects the attitude of a whole people toward culture and labor. Under Vietnamese traditions, everybody, from childhood, has to study and work for the betterment of his country. In old Viet-Nam the business career was usually practiced by uneducated and unskilled people, and was considered unproductive and these people dishonest.

Today businessmen are disliked by the Vietnamese people more than ever before. Corruption, inflation, and blackmarkets are classified "businesses" and constitute the living environment of busiressmen in the minds of the majority of the people. Parallel to this, foreign trade and many business enterprises are in the hands of expatriates. This results in a country where the business system is developed, but not well organized and not effectively managed. (Few people in the country have enough understanding of the national business process or possess enough business skills to be able to safeguard the nation's business interest, to enter and practice business, or to realize satisfactorily their own business of everyday living.) 
Many centuries ago in Viet-Nam there were mandarinal examinations which combined the functions of comprehensive examinations for degrees with civil service examinations. Successful candidates received degrees comparable to the Ph.D., M. A., B. A. and qualified for government positions. 1

$\checkmark$ Today business education in Viet-Nam could help remedy the deficiencies cited by creating a new class of businessmen who contribute to the development of their country and gain the esteem of their people.

Land, labor and capital are all key factors in economic development and in Viet-Nam, the effective utilization of human resources is a basic requirement to economic progress. Vietnamese education should make material contribution to its nation's economic development (Table $X X \mid 11)$. The task of business education, which is to provide personnel in the business field, must be an important part of the overall effort to invest in human capital formation in Viet-Nam. $\checkmark$ Anywhere in the world there is a vital need for well-founded general education to be supplemented and complemented by various types of vocational education, one of which is business education. This has been revealed through the analysis of the systems of education of a number of countries in America, Europe, and Asia which are either industrially developed or developing. It is believed with reasonable adaptations the principles of business education developed

${ }^{1}$ Foreign Service Institute, Viet-Nam Training Center Study Aid (Washington, D. C.: Department of State, 1968), mimeographed, P. 3 . 
TABLE. XXIII

BUSINESS EDUCATION AS A CONTRIBUTOR TO

ECONOMIC DEVELOPMENTa

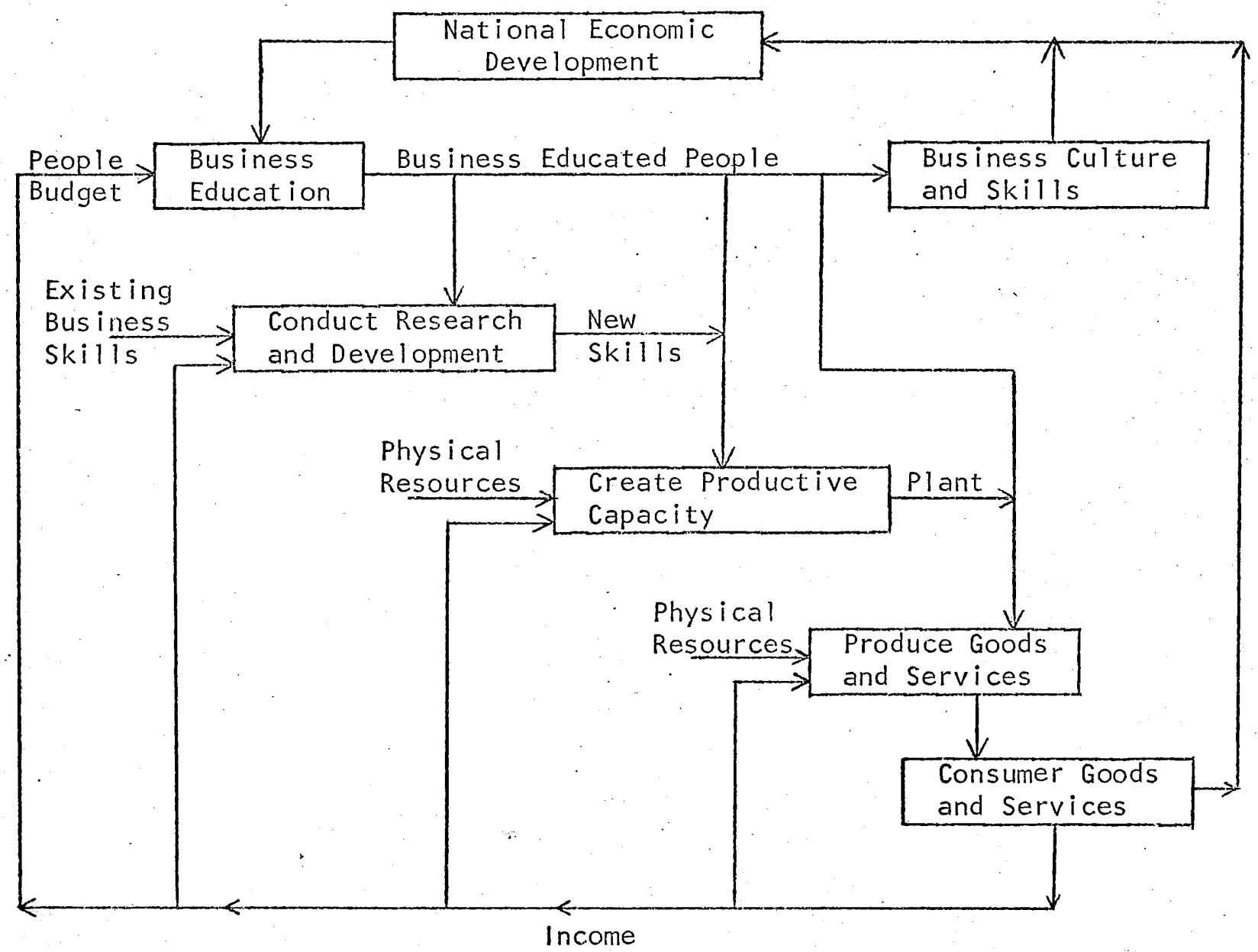

This diagram shows how Business Education contributes to Economic Development. The inputs are people and budget. The outputs are educated business people who perform the productive operations of the economic system.

a. Adapted from William J. Platt, "Educational Policy for Economic Growth," printed in Norman N. Barish and Michel Verhulst, Management Sciences in the Emerging Countries (New York: Pergamon Press, 1965), p. 141. 
and widely accepted in other countries may be applied in Viet-Nam.

$\checkmark$ Business education should be a related and an integral part of the Vietnamese total program of education. In turn, the educational system is an integral part of personal, occupational, and social living in a changing Viet-Nam society.

$\checkmark$ In Viet-Nam today there is great need of a qual if ied business managerial class and competent white collar workers to strengthen the national business system in order to facilitate the transfer of technology, to develop comnerce and industry, to achieve economic independence, and to accelerate rehabilitation after the war.

$\checkmark$ In addition, education in Viet-Nam needs to meet simultaneously the challenges of an increasing school population and the waste of human potential because the majority of secondary school students fail to complete their secondary education.

$\checkmark$ Business education with its diversified program needed for the national economic development is one of the solutions to the above problems. It resolves the problem of different levels of abilities and differences among students. It is also a means of realizing mass and practical education.

Culture is always considered important in any educational program but career is not less important in a developing nation like Viet-Nam. Vietnamese bus iness education should reconcile culture and career in order to provide competent employees, managers, and administrators who are also socially, emotionally, intellectually and civicly open-minded citizens. 
$\checkmark$ Business education will provide opportunities for all Vietnamese students to receive an understanding of the national business system and the role of industry and business in contributing to national and social welfare and progress through production and distribution. of goods and services. It also offers the understanding, attitudes, and skills needed for people to perform successfully in business occupations.

$V$ In developing business education in Viet-Nam, it is expected that the spirit of entrepreneurship will emerge at the same time that competent businessmen and white collar workers are provided to fortify the business system of the country and to realize an adequate national economic development.

$\forall$ The growth of business education should parallel the growth of the country and the education for business must be based on the needs of business and the demands of the enterprise system.

The aim of business education in Viet-Nam should be:

$\checkmark 1$. To develop a national business system which fits the national interest and the need of a developing country to cope with changes for progress. The Vietnamese business system in the future should be capable of paralleling the technological progress needed for the industrialization of national agriculture and for the development of industries required for the welfare of the people. Business education which is an integral part of the educational program is also the foundation of the national business system. It is a sub-system of the total educational system as well as a sub-system of the national business system (Table XXIV). 
TABLE XXIV

BUSINESS EDUCATION IN VIET-NAM

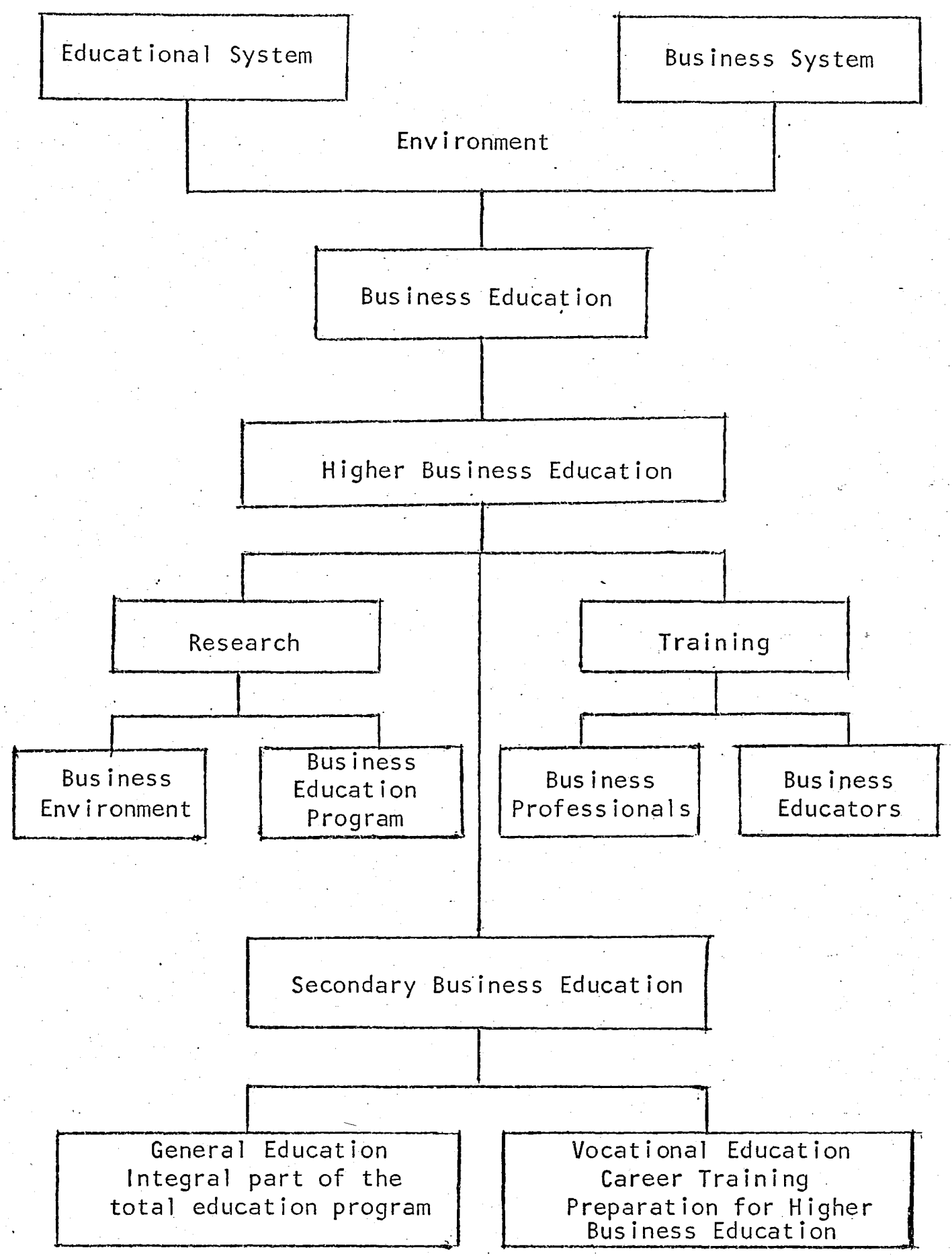


$v^{2}$. To educate Vietnamese youth to be able to understand the national business system and its trend in order that they will be able to (1) safeguard its interests, (2) rightfully benefit from the business system, and (3) adequately conduct their business activities of everyday living.

$\checkmark$ It is suggested that general business. education should be offered to all students at the upper secondary level (grades 10 to 12) in order to instill in students the sense of entrepreneurship, responsibility, organization and leadership in the business field. This is to prepare students for business experiences in which all citizens should be proficient both in knowledge and performance. Business education in this respect is the common knowledge that all enlightened citizens should have.

3. To prepare students who are interested and qualified in business for business employment. Business education, in this respect, is the main division of vocational education. It deals with the relationships, techniques, attitudes and knowledge necessary for business students to understand the Vietnamese social institutions of business and successfully to adjust to them. To carry out the vocational aim, business education should provide competent white collar workers, supervisors, managers, and administrators to government and bus iness enterprise.

$\checkmark$ Today's office personnel have become an important segment of the working force in the industrial establishments. The office represents the nerve center of business, industry, and government. Its responsibilities are to perform assistance to the complex task 
of unifying the various factors required for production of goods and services.

In advanced countries, a supply of qualified, educated and experienced office workers is usually available because there are preservice programs of education for business functioning in the universities, colleges, vocational schools, high schools, and private schools'. Such a supply of office workers does not exist in Viet-Nam. Since education is academically oriented, few qual ified business educators are available, and the need for better office workers has not been ident ified.

$\checkmark$ Future business students in upper secondary schools and universities will be the people who play important roles in the management of industry and government. They should be prepared to be conscious of their contributions to the efficient operation of private and public organizations that promote national economic growth.

\section{HIGHER BUSINESS EDUCATION}

\section{Phi losophy and objectives}

Business education should be an integral part of higher education in Viet-Nam. Because Viet-Nam is a developing, war-torn country it inevitably lags in various business and economic sectors. There is a need to be conscious of this lag in order to make a great leap forward. The universities in Viet-Nam should assume the responsibility of leading the Vietnamese youth into the business field and make them aware of their citizen duty of achieving national economic independence. The weakness of Vietnamese higher education is that it is highly 
academically oriented and little consideration is given to vocational education, especially business education. So far no Faculty of Business exists in any state university. The opening of the Faculty of Business in the state university is urgently required in order to remedy the weakness of an educational system which has led to an ineffective national business system and has slowed down the development of the nation.

$\checkmark$ At the higher level, business education should aim at:

1. Providing professional businessmen capable of assuming commercial, industrial or government responsibilities needed to achieve national economic independence and economic growth.

2. Providing business educators qual ified to teach business subjects in the universities and in the secondary schools.

3. Providing research necessary for developing a business education program parallel to the economic development of the country.

X4. Providing research necessary for the development of a sound national business system which fits with the interest of the people in a democratic society of an independent nation.

The above objectives are vital to the survival and the growth of a developing country.

Organization of Higher Business Education

$\checkmark$ The State Universities in Viet-Nam which absorb more than 80 percent of the total enrollment of higher education students should assume the responsibility of carrying out the philosophy and objectives of nigher business education in Viet-Nam. 
At the first stage of development of higher business education it is necessary to set up a Faculty of Business and a business educa.. tion teacher-training section at the Faculty of Pedagogy of the University of Saigon.

Saigon, which is a political and economic capital of Viet-Nam with an estimated population of 3,500,000 inhabitants, possesses favorable conditions for the development of business education. The National Institute of Administration and a Faculty of Law have been al ready located in Saigon, and this is the center of most important business and industrial activities. It would be convenient for the recruitment of the faculty staff, particularly part-time instructors among businessmen, and for providing research and practical work experiences for students. The Faculty of Political and Business Administration of the University of Da-Lat also holds its senior classes in Saigon. If the Faculty of Business of the University of Saigon operates with success, more new business education faculties should be opened at the other state universities as needed.

The opening of the business education teacher-training section at the Faculty of Pedagogy of the University of Saigon is highly important. Business education is being introduced and developed in two demonstration high schools and 12 pilot comprehensive high schools although no business teacher-training program has been realized at the Faculty of Pedagogy. So far there are only seven high school teachers who have been sent to the United States under the sponsorship of the Agency for International Development for training in business education. The objectives of the training abroad is to provide 
educators for the teacher-training program in business education at the Faculty of Pedagogy.

Usually the introduction of a new subject field in an educational program should be preceded by a teacher-training program. This should be done for the development of business education in Viet-Nam.

Besides the Faculty of Pedagogy of the University of Saigon, the other faculties of pedagogy can open their business education section if there is need of business education teachers in the area.

In the future it is proposed that every state university should include a Faculty of Business and a business education section for the training of business teachers at its Faculty of Pedagogy. (Table XXV)

\section{Curriculum Problems}

In Viet-Nam higher education is given in separate faculties of higher institutions. Each faculty offers one field of study and specialized courses related to it. Therefore there is no problem of the proportion of the program which should be devoted to general or vocational education. The problem to be resolved is the importance of the academic business courses and that of the specialized courses.

$\checkmark$ The program of higher business education which aims at educating businessmen and educators should be evaluated in relation to the changing need of the society and to the research in the area of business. At the present time no research is available to provide information as to what constitutes a good program in business education in Viet-Nam. It is suggested that the starting program of higher business education will coricentrate on business organization and management at the 
TABLE XXV

ORGANIZATION. OF HIGHER BUSINESS EDUCATION

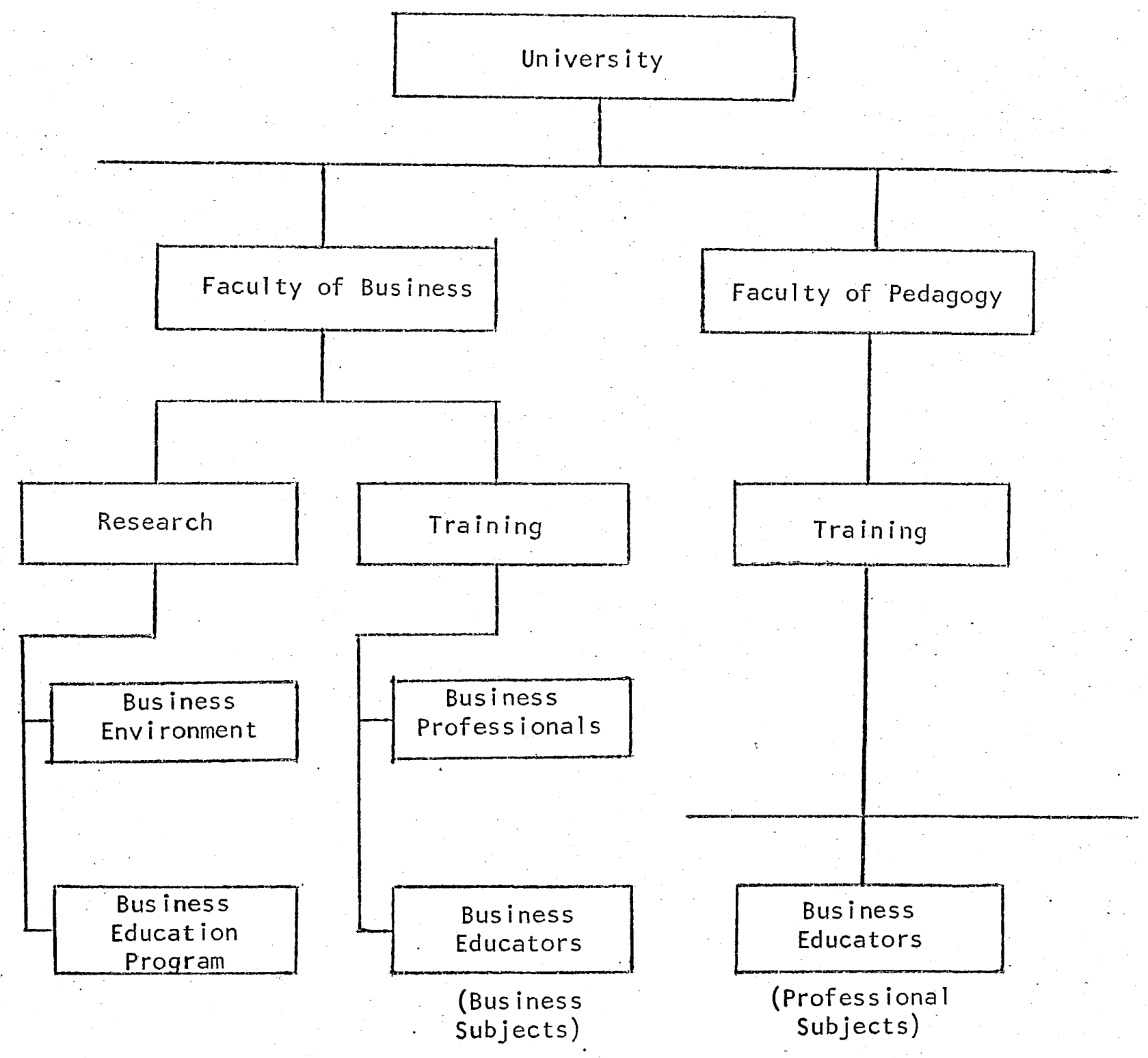


executive level. It is in the preparation for business management that the breadth of knowledge is important. The real need of business education in Viet-Nam at the present $t$ ime is for minds which are capable of judgment in business decisions. Business education at the university level should have the high probability that the program will provide a suitable bas is for the development of creative and rational minds which are indispensable to business leaders.

$\checkmark$ The program of higher education in business at the university level in Viet-Nam should include a broad general business education background which consists of academic courses in economics, finance, accounting, statistics, business law, management, research, foreign languages, etc. These courses are basic fundamentals in the education of leadership for business organization and management. The specialized courses such as office management, managerial accounting, distribution management, computer programming, etc., which provide certain skills and marketable tools needed by students to find employment will depend on the development of industry and economy or the need of the urban area. The implementation of these specialized courses in the program requires intensive and continual research and surveys of business trends and developments.

A concentrated program in economics and finance as a basis for business education is necessary. The economic area may include principles of economics, political economy, the economy of Viet-Nam, the market economy, the theory of the firm, labor economy, economic development, the role of money. The area of finance may include financial institutions, financial management, corporate finance, money 
and banking. These are vital subjects of a business training program. The study of economics and finance which is an integral part of a liberal education can offer a significant contribution to the training of business executives and is a sound background for business as well as for public leadership.

$\checkmark$ Business does not operate in a vacuum but in an organized environment with law and order. The business student has to learn how to conduct a business in accordance with the established standards and rules of law that pertain to wages, labor, financing, taxation and other matters which are essential to the successful conduct of a business. Business law contributes to the training for business by acquainting students with the legal principles which establish the economic climate in which business operates.

A study of accounting principles and practices is also needed for a successful career in business. Accounting has to be concerned with nearly every phase of business operation. The measurement of income and profit is a prime function of accounting and business income is really an accounting concept. The statement "accounting is the language of business" undoubtedly reflects the importance of accounting in the business environment.

Statistics and research also fulfill important functions in business education. Such courses enable the student to familiarize himself with the techniques of using data and methods of inquiry and reasoning which are invaluable to his business career. The sense of leadership and organization should be implemented in the student's mind through a number of business organization and 
management courses. These courses make him understand that the work of the business world is accomplished by organized human effort which is intelligently administered and managed by business leaders. The program of study related to management should stress business communication and human relations which are important factors in the business environment of a democratic society.

$\sqrt{ }$ As the economy develops there is an increasing need for office personnel in government and industry. Specialized courses in. industrial management, secretarial studies, office education, electronic data processing, etc., should be offered on a specialized business education basis. Business skill courses such as typing, shorthand, stenography, card-punching, and business machines are considered component subjects of the specialized business education field and can be taken by students on an elective basis.

The Vietnamese business environment is different from that of advanced industrialized countries where specialization has been realized at high levels. The vietnamese higher business education student should acquire, at the University, a broad background of basic general business education which will allow him to adapt comfortably to rapid.changes in a developing country.

It is strongly suggested that at the university level the businessman and the educator should follow the same requirements of basic general academic business subjects as well as specialized courses in the chosen business field. The difference between the training of the businessman and the training of the educator is that the future businessman will have more research and practice in his 
specialized fields while the future educator will have to take professional teaching courses which include teaching practices.

\section{Faculty Problems}

The academic full-time staff at a Faculty of the Vietnamese university consists of full professors, associate professors, assistant professors, and instructors. Candidates for the post of assistant professor and above must hold a doctor's degree. Academic state university staff comes under civil service regulations governing salaries, allowances, and pensions. Staff members are required, by their terms of appointment, to teach from three to eight hours a week. Scholars from abroad are offered posts as temporary lecturers. A number of university teachers also hold administrative posts in government departments or in private enterprise.

Recruiting professors for a new faculty is a serious problem. However, at the beginning, the following members are believed to be qualified for either full-time or part-time professors or instructors at the newiy-created Faculty of Business:

1. Professors and instructors who are teaching at the Faculties of Law of Universities, at the Finance and Economics Section of the National Institute of Administration, or at the Business Section of the Faculty of Political and Business Administration at the University of Da-Lat.

2. Graduates from the Faculty of Law of Vietnamese or foreign universities who hold a doctor's degree or a diploma of higher studies in Economics or Finance. 
3. Graduates from American Universities who hold a Doctor's degree or a Master's degree in Business Administration or Business Education.

4. Graduates from the National Institute of Administration who hold a diploma of higher studies in general administration or in Economics and Finance.

5. Government officials graduated from the graduate section of the National Institute of Administration.

6. Industrialists and businessmen in Saigon.

Graduate studies in business education should be offered from the fifth year after the opening of the Faculty. Therefore it is necessary to send immediately a number of graduate students who have a Licence of Law, or a Licence of Political and Business Administration, or a diploma of higher studies in Economics, to foreign universities for training leading to the Doctor's degree in Business or a related field. It is hoped that they will complete their training within four or five years and the Faculty will have available professors when it offers graduate studies.

\section{SECONDARY BUSINESS EDUCATION}

\section{Philosophy and objectives}

$\checkmark$ The fact we are facing in 1970 , as shown by statistics from the past seven years, is that 76 percent of the school population, age 12 to 18 , could not find a place in high school) while 85 percent of secondary education students drop out of high school or fail to complete Baccalaureat 11 . While there is considerable wastage of 
human power, there is a great need of human capital formation. Well trained blue collar as well as white collar workers, supervisors, and managers are needed in every sector of the economy for rehabilitation and development of a war-torn developing country. The development of vocational education parallel to the development of academic education may be a solution to the above problem.

A population of $22,500,000$ is projected in 1978, with 4,100,000 of secondary school age. Secondary school enrollment should increase from 471,000 in 1968 to $1,355,000$ in 1978 with about 30 percent or 452,000 students in vocational schools. A proportion of these vocational students should be trained in business education.

$\checkmark$ (The primary purpose of business education in the vietnamese. high school is to prepare youth for business employment.) Business education also contributes to secondary general education and to the hot

preparation of college-bound students for higher business education.

The objectives of secondary business education in Viet-Nam should be:

1. To provide knowledges, attitudes, and skills needed by all people to be effective in their own personal business life and in their contribution-mas a good citizen--to the development of the nation's business and economy.

2. To provide orientation and preparation needed for students who will pursue higher business education.

3. To provide vocational knowledge and skills needed to perform successfully a business occupation after completion of high school. 
Business education contributes to general education and general education is incomplete unless it contains experience in the type of bus iness education that is essential to all. If the above view is acceptable, business education should be provided in all upper secondary schools in Viet-Nam. The mission of the high school with respect to vocational business efficiency should be:

$\checkmark 1$. To provide exploration by giving pupils opportunities to discover the ir interests, capacities, and business vocations.

$\checkmark 2$. To provide guidance and preparation for more advanced study in education for business at the university level.

3. To provide a basic general business education and preparation for a business career that will enable one to perform satisfactorily a business occupation and to adapt to fast changes and developments in business fields.

$\checkmark$ At the secondary level business education should make a tangible contribution toward offering something practical and specific for the adjustment between school and life. Since a large percentage of the high school students (70 percent in 1969) do not graduate, it is also the obligation of business education to provide job training for them.

The vocational business education program should be justified by the needs of the community, the urban area, or the nation. To be adequate, a vocational business program should qual ify students upon completion of high school for employment without any additional business training. There should be evidence of needs, demands, and opportunities before implementing a new program. The student should 
be advised and guided into selecting a program that will result in at least one definite skill being developed to satisfactory job competence. If possible, a plan should be developed in cooperation with local business and government in order to provide work experience under job standards.

Vocational business education in the Vietnamese high school should not, in any case, be offered in lieu of general academic education--it should supplement and enhance it. General business education or vocational business education at the secondary level is an integral part of the total educational program.

Organization of Business Education at the Secondary Level

Adopting the democratic ideal in education, the vietnamese high school along with the elementary school will have to become the common school for all. Faced with the increasing secondary school age population and the national policy of mass and practical education, it is necessary to shift the emphas is from education appropriate for a relatively few able students to the complicated task of education for the great mass of students with different levels of abilities and aptitudes. The present system of secondary education which is based on selection at a very early level (at the sixth grade) and which is geared to the requirements of the few ignores the mass of the population.

To realize mass and practical education, a diversification of education should be applied at the secondary level. Secondary education should provide opportunities for the individual to find himself a 
useful place in society and to earn a living commensurate with his abilities.

The need for developing business education in high schools was identified by the Ministry of Education in 1965 in the five-year plan. Provisions were made in this plan for high schools to become comprehensive. In the school year 1968-69, 11 high schools changed their name to comprehensive pilot high schools to experiment with a program of comprehensive secondary education.

$\checkmark$ The proposed curriculum of the experimental comprehensive pilot high school consists of a program of general requirements for all students and a program of electives for students of all interest and abilities. Besides subjects in the areas of the practical arts, such as industrial arts, business education, home economics, and agriculture, the curriculum also offers excellent academic programs for those students preparing to go on to higher education. 1

At the present time boys and girls who pursue education beyond the high school level in Viet-Nam are a minority. The majority of students should be prepared for initial employment upon completion of high school. The question to be answered about the Vietnamese comprehensive high school is whether, in Viet-Nam's environment, the comprehensive school has enough teachers and facilities to fulfill satisfactorily the following functions:

1. To provide a good general education for all pupils as future citizens of a democracy.

${ }^{1}$ Thumbuc Demonstration School, The Comprehens ive High School Curriculum, unpublished, 1968. (This proposed program is under study at the Ministry of Education.) 
2. To provide diversified programs for the majority to develop useful knowledge and skills for employment after graduation.

3. To educate adequately able students whose vocations will depend on their subsequent education at the university level.

The answer to the above questions will decide whether or not we should develop vocational business education in the Vietnamese secondary comprehensive school.

So far, Viet-Nam adopts a two-track system of secondary educam tion: the academic high school and the technical vocational high school. The technical high school which offers courses leading to the technical baccalaureat is equivalent to any academic high school. The third new track of the comprehensive high school is in experimentation and the comprehensive high school program is under study.

Business education is being taught at the secondary level at the National school of Commerce for adults, and is being introduced in the comprehensive pilot high school.

In order to realize an adequate development of business education at the secondary level, it is suggested that:

1. The National School of Commerce should remain a business school for adults. The enrollment of the school should be increased to answer the need of the adult students and to satisfy the demand of business workers of the Saigon area. The program should be upgraded by creating major fields of business training instead of a common program for all students.

2. The past development of business education should be reviewed in terms of the philosophy and objectives of the program, the 
qual ifications of the teachers, and the contents of the curriculum as related to the environment. The teaching of business education in the comprehensive pilot high school should be continued in order to experiment with a business education track in a multi-track school.

3. An upper secondary business high school should be opened. This school should have equal status with the upper secondary technical high school or the upper secondary academic high school. The business program should be equivalent to the business stream program of the comprehensive pilot school. A three-year course leading to the baccalaureat in business will be offered to students starting Grade 10 . While the National school of Commerce is a terminal business school for adults, the upper secondary school is a business school for secondary school age students. The baccalaureat in business will qualify students for initial employment or will allow them to continue further study in business education at the university level.

By concentrating business vocational preparation in specialized business schoois it is possible to provide better equipment and instruction with less duplication and cost.

$\left\{\begin{array}{l}\text { In the future, if the development of industry and economy } \\ \text { requires white collar workers and technicians at higher levels, post } \\ \text { high school higher specialized courses should be offered and the } \\ \text { business high school will become a combined bus iness high school and } \\ \text { junior business college. }\end{array}\right.$

The first business high school should be opened in Saigon where the environment of a large business city offers favorable conditions for the development of business education. If facilities and teachers 
are available and the needs of the students and the demands of the urban areas are identified more business high schools can be opened in large cities.

The business high school in Saigon and the business education track of the Thu-Duc Comprehensive Pilot high school should serve as laboratory schools for the student-teachers in business education at the Faculty of Business or at the Faculty of Pedagogy. These above two schools will be involved in the following research experiment: what organization is more suitable for the development of business education in a developing country like Viet-Nam--a multi-track comprehensive high school or a specialized business high school?

It is evident that the purpose of Vietnamese education has become more democratically oriented with broad aims that include equal opportunity for intellectual, personal, vocational, social and economic attainment. The immediate large-scale modifidation, in terms of approaching a single-ladder system with specialized tracks in a common school is imperative; however, the conflict between goal and means calls out for consideration.

In the long run, the three kinds of Vietnamese high schools-the traditional high school, the vocational high school, and the comprehensive high school--can evolve slowly but with success into a multi-track or comprehensive institution if the latter proves its success in secondary education.

$\sqrt{4}$. Private secondary professional business education institutions should be encouraged to improve their programs and favorable conditions should be created to facilitate their development. Besides 
the typing certificate and the accounting certificate, it is suggested that the Department of. Education organize examinations for other business certificates that will qual ify the holder for employment in government or private offices. This will motivate the private institutions to expand their programs as well as encourage adults to attend private business professional schools.

There are many private business education institutions in Saigon and in the other large cities of Viet-Nam, and their numbers are increasing. This field of adult business courses usually includes scores of short and relatively specialized courses in typewriting, shorthand, accounting, translating, and secretarial practices devised to meet the specific educational needs of the urban area. The official examination organized by the Department of Education is also a means of standardizing and controlling the private business education which constitutes but one segment of the national effori toward adult vocational education in Viet-Nam.

$\checkmark 5$. General business education should be introduced in the curriculum of the traditional academic high school as an integral part of a complete secondary program. The present four-year program of civics at the first cycle can be taught at Grades 6,7 , and 8 . The two periods each week of civics at Grade 9 should be devoted to a general business education course which is offered for its exploratory and information values. The high school student at Grade 9 may have reached that point in education at which. it is desirable to begin to think in earnest about a future career. Upon entering the second cycle of high school at Grade 10 the Vietnamese student is faced with 
the necessity of choosing among various curriculums, each leading to a different career. Therefore a course of general business at Grade 9 is important and necessary to give the student a better understanding of the diverse business careers which will be open to him in the future.

At the second cycle, a program of economics, a component subject of business education, al ready exists as a program of civics at Grade 11. This course heavily emphasizes economic theory. In order to be practical a program of applied economics should be developed which should include consumer economics and Viet-Nam business and economic organization and survey. It is also suggested that the unit "the Vietnamese business and economic system; its characteristics and prospects of development" be included in the program of civics at Grade 12 , the last high school year, in order to instill in future citizens a serse of responsibility toward their national business economic system and its development.

Curriculum Problems

It is proposed that the business education program for the business high school of the business education track of the comprehensive high school should be on a strong general and academic business education bas is in order to conform to the present Vietnamese education system which is highly specialized at the university level. (The curriculum should embrace basic academic business courses, specialized business courses, and business skill courses.)

$\mathcal{J}$ (The basic academic business courses consist of basic general business courses and vocational basic academic business courses. 
$\checkmark$ A basic general business area includes a contribution to general education in the area of citizenship, intelligence, consumption, and general economic and business understanding. To effect this, the curriculum should offer a general business course which contains Viet-Nam business and economic organization, consumer economics, bus iness law, business for everyday living, etc. Academic vocational courses provide vocational business students with a broad general business background which will enable them to study specialized business fields and skills, allow them to adapt to occupational changes, or to go on for further business studies at the university level. The basic vocational academic courses include elementary economics, accounting, finance, business principles and management, business organization and survey, business. law, money and banking, etc. Basic business academic courses should be required of all vocational students in business.

$\checkmark$ Specialized business courses should be strictly based on surveys of the needs of government and private enterprise. These courses should include office education and secretarial practices, accounting, indistrial management, data processing, etc.

$\checkmark$ The basic business courses should cover all three years and the curriculum should provide for cont inuous development of other academic subjects to avoid undesirable overlapping. It is desirable that the specialized business courses should be placed as near to the end of the three-year course as possible. After completion of the specialized business courses, the students should have occupational skills proficient enough for initial employment. A graduate of the bus iness 
high school should meet the job standards requirements in his selected skills.

$\checkmark$ A business student can take business skills courses such as typing, shorthand, business machines, stenography, and card-punching on an elective basis for personal competence or for the requirements of his major business field.

$\checkmark \quad$ It is also suggested that the curriculum be divided as follows: 50 percent for general education such as Vietnamese literature and writing, foreign language, mathematics, civics, and social sciences; 30 percent for academic basic business subjects; and 20 percent for specialized business.

Faculty Problems

The secondary school staff consists of full-time and part-time teachers. Candidates for full-time teachers at the upper secondary level must hold a certificate of teaching second cycie high school, after completion of a four-year course at the Facul ty of Pedagogy, or a Licence from the other faculties. So far the business education training program has not been realized at any faculty of pedagogy and no trained business education teachers are available. Based upon the analys is of the educational program and requirements for full-time upper secondary teachers, the following people may be recruited as business teachers:

1. graduates from the Faculties of Law of Universities holding a Licence or a Diploma of Higher Studies in Economics.

2. graduates from the Faculty of Political and Business Administration of the University of Da-Lat majoring in Business 
Administration.

3. graduates from foreign universities holding a degree in Business Administration or Business Education.

4. graduates from the National Institute of Administration.

The above do not possess any background in the teaching profession and are qualified for a number of business academic and specialized courses but not in business skill courses. Pre-service accelerated training for professional background as well as for specialized business education should be provided for them.

Temporarily, the business teachers for skill courses such as typewriting, shorthand, and business machines can be found through the Shorthand, Typewriting, and Accounting Association of Viet-Nam. These teachers would be part-time teachers if they do not hold a university's degree.

The above solution is aimed at providing business education high school teachers at the beginning stage of business education development. In the future, as the needs of business education become officially identified and the programs become an integral part of the secondary educational program, the Faculties of Pedagogy of the Universities in cooperation with the Faculty of Business education should provide business education secondary school teachers' training. The business education teachers' training program will be a one-year course for candidates holding a Licence in Law or in Political and Business Administration, or a three-year course for candidates holding a Law certificate, or a four-year course for candidates holding only the Baccalaureat. 
The tendency to require a broad professional background and appropriate, adequate, actual business experiences is imperative; however, it is rare for one to start a career as business teacher. with such requirements. This kind of business teacher will be found in the next few years if the philosophy and objectives and the needs for development of business education in Viet-Nam are officially identified.

\section{SUMMARY ON THE PROPOSAL}

Business education should be developed in Viet-Nam as an integral part of a total educational program. It is urgent for the achievement of economic independence and economic growth of the nation. It aims at strengthening the national business system, providing business understanding to all students in a complete program of general education, and training vocational students for business careers.

A faculty of business and a business education teacher-training section at the Faculty of Pedagogy should be created in a state university parallel to the development of business education in the comprehensive pilot high schools and in the newly-created business high schools.

General business education should be offered at Grade 9 and applied economics at Grades 11 and 12 at the traditional academic high schools (Table XXVI).

Private business institutions should be encouraged, as one segment of the national effort, to develop adult vocational education.

The training of high school business teachers can be realized. by the faculty of business and the faculty of pedagogy. 
TABLE XXVI

GENERAL OUTLINE OF THE.PROPOSED BUSINESS EDUCATION SYSTEM

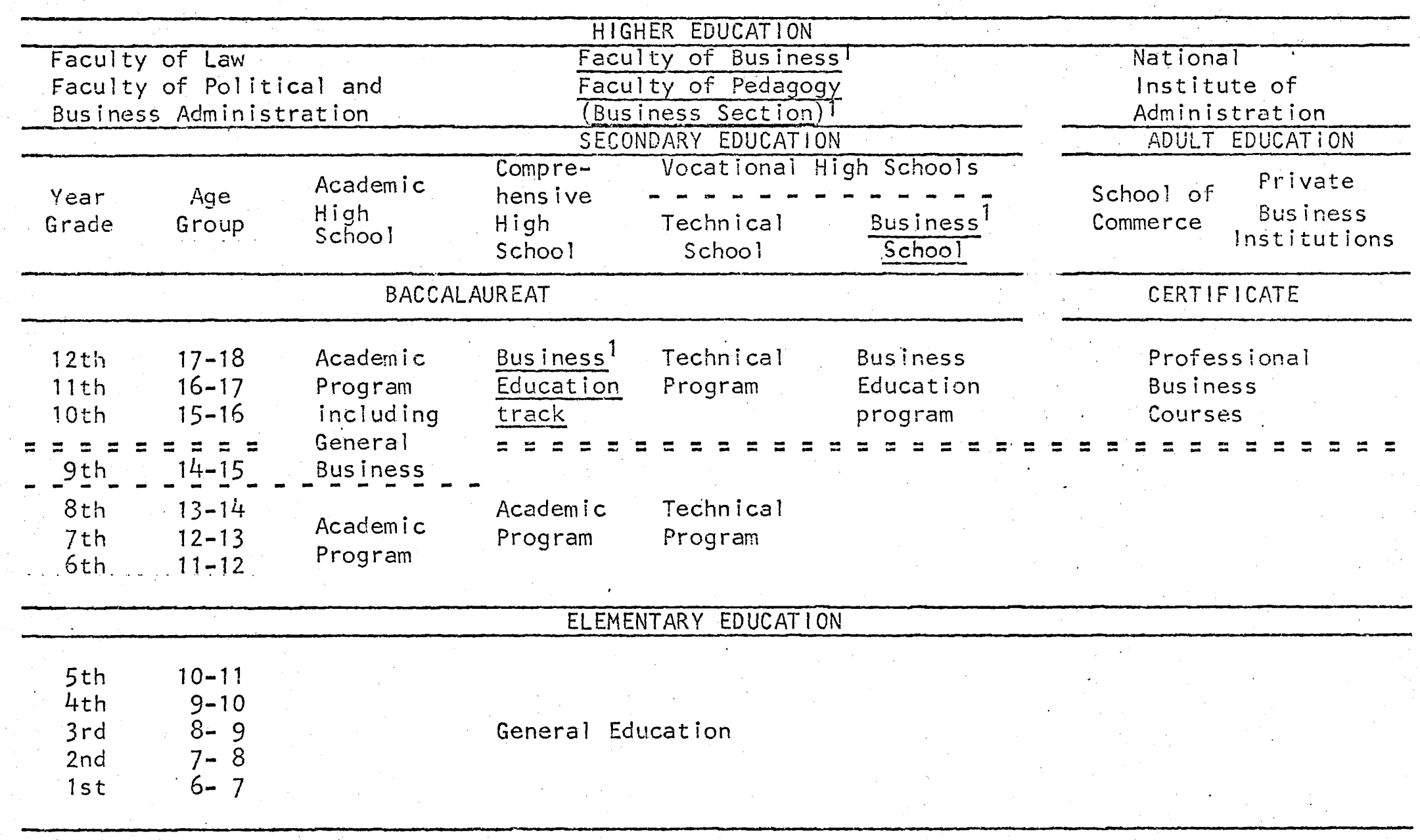

${ }^{1}$ New schools or new programs. 
Graduate students should be sent abroad for training as business education professors at the university level.

The program of business education should embrace a broad field of general basic business education which will allow students to adapt to fast changes in the business field and specialized business - subjects which fit the students to business careers. Business skills courses should be taken by students either for personal competence or as a component of the specialized business major. As an interim measure, professors and teachers of business education are available for recruitment from various sectors; however, a business educator' training program should be planned and realized as soon as possible. This is vital to a bus iness education development program. 
BIBL IOGRAPHY

I. BOOKS

American University. Area Handbook for South Viet-Nam. Washington, D. C.: U. S. Government Printing office, 1967.

- Area Handbook for Thailand. Washington, D. C.: U. S. Government Printing office, 1966. DS 5

Anderson, Donald S. Japan: Three Epochs of Modern Education. Washington, D. C.: U. S. Department of Health, Education, and Welfare, 1959.

Barish, N. and Michel Verhulst. Management Sciences in the Emerging Countries. New York: Pergamon Press, 1965.

Bo Quoc-gia Giao-duc. Choung-trinh Trung-hoc. Saigon: Bo Quoc-gia Giao-duc, 1965.

- Giao-duc Viet-Nam 1965. Saigon: Nha Nghien-cuu va Ke-huach Bo Quoc-gia Giao-duc, 1965.

Caroll, Thomas H. Business Education for Competence and Responsibility. Chapel Hill: The University of North Carolina Press, 1964.

Chi Nam Sinh-Vien Dai-hoc Saigon. Saigon: Ministry of National Education, 1966.

Conant, James b. Recommendations for Education in the Junior High School Years. Princeton: Educational Testing Services, 1960. 1959. - The American High School Today. New York: McGraw-Hill, - The Comprehensive High School. New York: McGraw-Hill, 1967.

Dao, Duy Anh. Viet-Nam Van-Hoa Su-Cuong. Saigon: Xuat-ban Bon Phuong, 1951.

Educational Policies Commission. The Purpose of Education in American Democracy. Washington, D. C.: National Education Association, 1938. 
Everett, Samuel. Growing in English Secondary Schools. Michigan: University of Pittsburgh Press, 1959.

Good, Carter Victor. Dictionary of Education. New York: Mc.Graw-Hill, 1959.

Good, H. B. History of American Education. New York: The MacMillan Company, 1956.

Gross, Richard E. British Secondary Education. London: 0xford University Press, 1965.

Hayden, Howard. Higher Education and Development in South-East Asia. Belgium: Unesco and the International Association of Universities, 1967.

Japanese Commission for Unesco. 'Guide to Study in Japan. Japan: Japanese Commission for Unesco, 1962.

Kroneriberg, Henry H. and Rudyard K. Bent. Principles of Secondary Education. New York: McGraw-Hill, 1966.

Lindholm, Richard $W$. Viet-Nam: The First Five Years. Michigan: Michigan State University Press, 1959.

L'Institute Pedagogique Nationale. Encyclopedia Pratique de l'Education en France. France: Ministere de l'Education Nationale, 1960.

Male, Georges A. Education in France. Washington, D. C.: U. S. Department of Health, Education and Welfare, 1963.

Mynt, HLa. The Widening Gap of the Underdeveloped Countries. New Haven: Yale University Press, 1965.

National Bank of Viet-Nam. Estimations of National Income of Viet-Nam in 1965. Saigon: National Bank of Viet-Nam, 1955.

Norton, Thomas L. Public Education and Economic Trends. Massachusetts: Harvard University, 1939 ,

Spencer, Daniel L. and Alexander Waronick. Technology of Developing Countries. New York: Frederick A. Praeger, 1967.

Spencer, Herbert. Education: Intellectual, Moral and Physical. New York and London: D. Appleton and Company, 1910.

Taylor, William. The Secondary Modern School. London: Faber and Faber, 1963. 
Tonne, Herbert A. Principles of Business Education. New York: McGraw$\mathrm{Hi} 11,1961$.

- The Scope of Social Business Education. (National Symposium on Socio-Bus iness Education, Monograph 31.) Cincinnati: SouthWestern, 1936.

Tran, Trong Kim. Viet-Nam Su-Luoc. Saigon: Nha Xuat-ban Tan-Viet, 1958.

Unesco. International Yearbook of Education. Geneva: International Bureau of Education, 1966.

- Unesco Statistical Yearbook. 1966.

- World Survey of Education 1. Paris: Les Petits Fils de Leonard Daniel, 1955.

- World Survey of Education 11. Zurich: Berichtaus, 1958.

- World Survey of Education 111. Zurich: Berichtaus, 1961.

- World Survey of Education IV. Tournai: Custerman, 1966.

United Nations. Monthly Statistics. 1968.

- Statistical Yearbook. 1968.

- Toward the Economic Development of the Republic of Viet-Nam.

New York: United Nations, 1959.

United States Bureau of Education. Cardinal Principles of Secondary

Education. Washington, D. C.: Government Printing Office, 1918.

United States Congressional and Administrative News, 88th Congress, First Session, 1963. New York: Edward Thompson Company, 1963.

University of Saigon. Saigon University Bulletin. Saigon: Ministry of Education, 1966.

Vu, Quoc Thuc and Joint Development Group. The Postwar Development of South Viet-Nam--Policies and Programs. Saigon: Joint Development Group, 1969.

Werstler, Richard Emerson. The Schools in Europe. Michigan: Swenk Tuth Press, 1967.

Willard, France M. The Republic of India. World Education Series, 1964. 


\section{I1. PERIODICALS}

Hamm-Brucher, Hildegard. "Changes Planned in the Education System of the Seventies," The German Tribune. March 10, 1970.

Howard, Milton E. "A Suggested Curriculum for Preparation of Business Teachers," Business Education World. December, 1965.

Lecompte, Albert. "Business Education in France," National Education Quarterly. Spring, 1960.

Policies Commission for Business and Economic Education. "This We Believe about Business Education in the High School," Business Education Forum. May, 1961.

"The Functions of Prevocational Preparation in Business Education," Business Education Forum. May, 1969. - "Business Education for the CollegemBound Students," Business Education Forum. May, 1964.

Smythe, Hugh $H$. and Nibondh Sasidhorn. "Educational Planning in Thail and," Comparative Education Review. June, 1963.

Soemarsono. "Business Education in Indonesia," The National Education Quarterly. March, 1960.

Viet-Nam Embassy. "Training the Supervisors," Viet-Nam Bullet in, VietNam Information Series No. 7. Washington, D. C.: Embassy of Viet-Nain, 1969.

Wagenen, Rulon C. Van. "Vocational Business Education in California," The National Business Education Quarterly. Winter 1965-66.

Wells, Inez Ray. "Business Education in the Multipurpose Schools of India," The National Business Education Quarteriy. March, 1962.

Wooschloger, Ruth. "An Appraisal of Attacks on Business Education since Sputnik," The Business Education Quarterly. Winter, 1961. 